\title{
A Roman Structure from Hurbanovo, SW Slovakia: Multiproxy Investigation of Unique Waterlogged Deposit
}

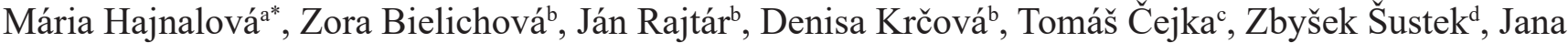 \\ Mihályiováb
}

${ }^{a}$ Department of Archaeology, Faculty of Arts, Constantine the Philosopher University Nitra, Hodžova 1, 94974 Nitra, Slovakia ${ }^{b}$ Institute of Archaeology, Slovak Academy of Sciences, Akademická 2, 94921 Nitra, Slovakia

cPlant Science and Biodiversity Center, Institute of Botany, Slovak Academy of Sciences, Dúbravská cesta 9, 84523 Bratislava, Slovakia ${ }^{d}$ Institute of Zoology, Slovak Academy of Sciences, Dúbravská cesta 9, 84506 Bratislava, Slovakia

\section{ARTICLE INFO}

Article history:

Received: $2^{\text {nd }}$ March 2018

Accepted: $19^{\text {th }}$ July 2018

DOI: http://dx.doi.org/ 10.24916/iansa.2018.1.4

\section{Key words:}

Roman period

waterlogged fill

archaeobotany

archaeozoology

palaeoenvironment

subsistence

technology of wood

retting

\begin{abstract}
A B S TRACT
The paper presents results of analyses of various types of organic remains recovered from a waterlogged fill of the sunken structure from Hurbanovo (SW Slovakia) dated to the Early Roman period $\left(1^{\text {st }}\right.$ and $2^{\text {nd }}$ century AD). The structure represents a unique find - the only archaeological feature with waterlogged infill at the site and one of nine known from the Roman Period "barbaric" territory of modern day Slovakia. The waterlogging enabled the preservation of a wider spectrum of organic remains and taxa as known from contemporary Roman period sites in the region. Here are discussed charred and waterlogged seeds and fruits, waterlogged wood, charcoal, animal bones, molluscs and insects. Floral and faunal data yield evidence of crop and animal husbandry, domestic/household activities at the site, and convey information on the surroundings and human-exploited landscape. Taphonomic analyses indicate that the majority of ecofacts from the pit are in the secondary position, and therefore cannot be used for ascertaining the original function of the structure. This has been done solely on archaeological analyses of the contextual data and by use of analogy.
\end{abstract}

\section{Introduction}

In the Middle Danube region of east-central Europe, waterlogged archaeological sites - or even single features are rare ( $c f$. Ottó, Gábor, 2012; Maixnerová, 2015). Therefore, when in 2003 a waterlogged pit with an abundance of wooden finds was discovered in Hurbanovo (Slovakia), it was a local sensation. The decision was made to rescue as much eco- and naturfacts preserved in the sediment as possible. Nevertheless, the winter time and lack of equipment strongly influenced the method of excavation and sampling. The infill was taken in bulk to be processed later in the laboratory. Subsampling of bulk samples, their flotation as well as the recovery and conservation of wooden artefacts, was done immediately. The final evaluation of the recovered materials proceeded only after securing the Roman period date of the

*Corresponding author. E-mail: mhajnalova@ukf.sk plant and invertebrate remains, achieved by AMS in 2017. The aim of this paper is to present the most important results from the multidisciplinary research of organic finds and to discuss their potential for improving our understanding of the environment and subsistence of south-western Slovakia during the Early Roman period.

\section{Background information on site}

The region of Hurbanovo, situated in the south-eastern part of the Danubian lowland (south-western Slovakia) near the confluence of the Nitra and Žitava rivers, had been intensively occupied since early prehistory (e.g. Ratimorská, 1998). The site at Hurbanovo-Štrkovisko is only a small part of one of the most extensive archaeological settlement sites situated in the southern limits of the town. It occupies the slightly elevated sand dune ridge stretching a length of 

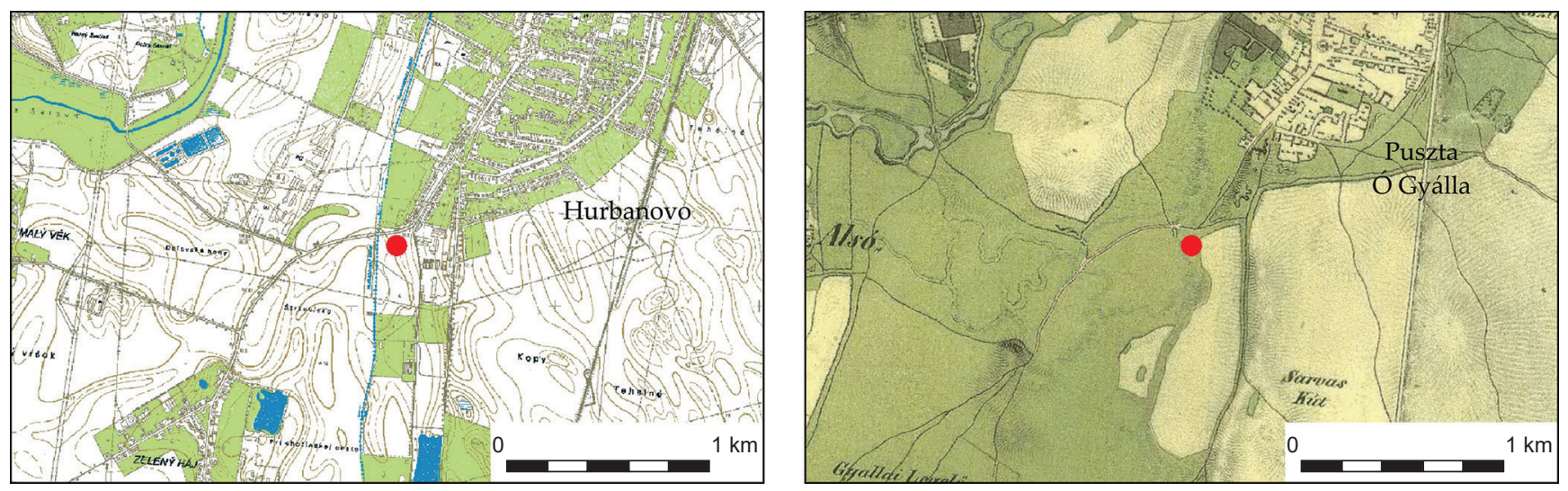

Figure 1. Hurbanovo-Štrkovisko; geographic location $\left(47.86027^{\circ} \mathrm{N}, 18.18335^{\circ} \mathrm{E}\right)$. Map of $2^{\text {nd }}$ Military survey $(1806-1869)$. http://www.mapire.eu

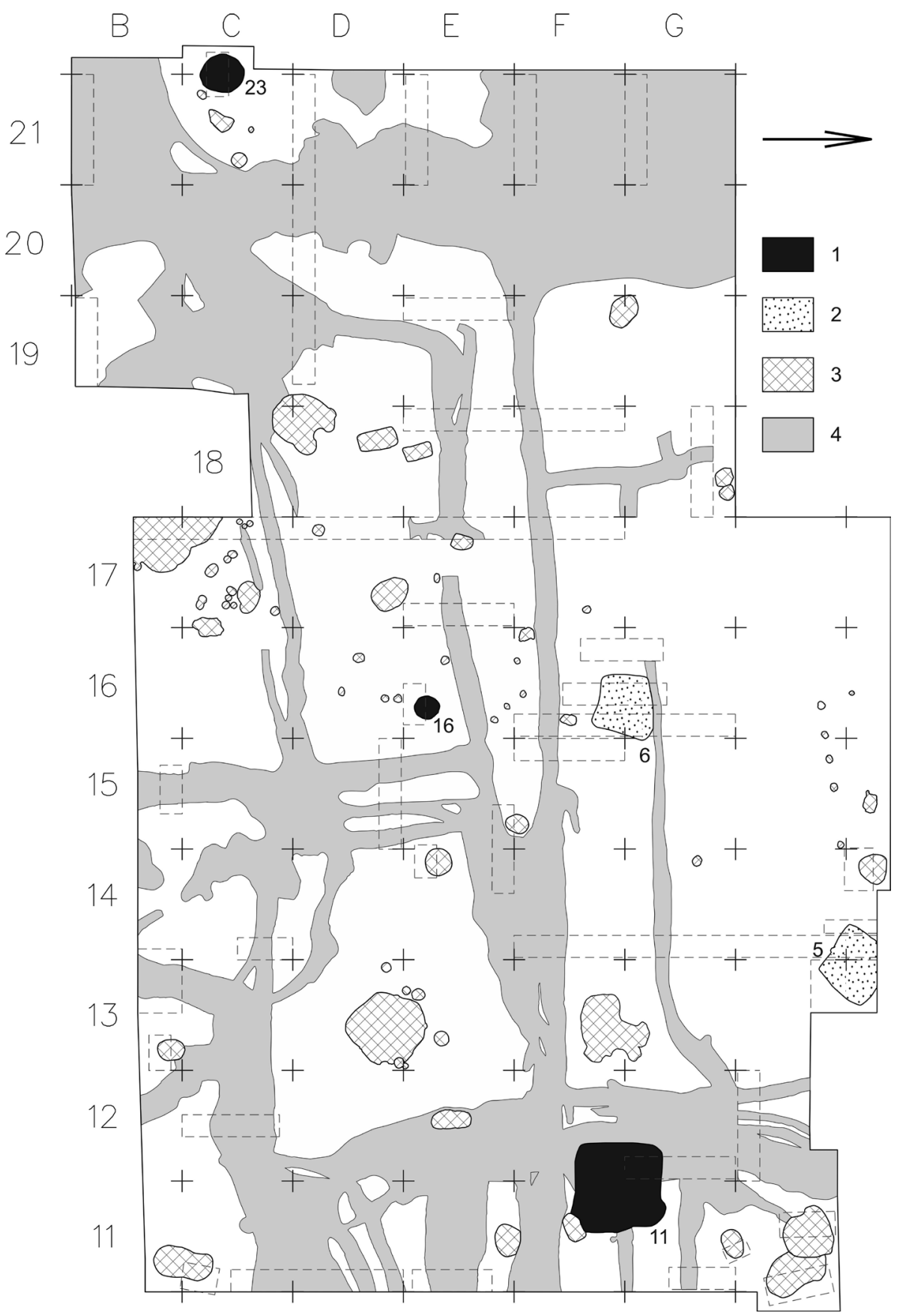

Figure 2. Hurbanovo-Štrkovisko; plan of the excavation. Legend: 1 - Roman period; 2 - Early Middle Ages; 3 - other prehistoric periods; 4 - unknown 
ca $1 \mathrm{~km}$, from the southern limit of the town to the village of Konkol'. The ridge runs north to south and in the west borders with a terrain depression, the eastern margin of a marsh of the recently-channelled Hurbanovo stream (Figure 1). Aerial and field prospection has documented that the whole extent of the sand dune and nearby terrain has been exploited and densely occupied throughout prehistory, protohistory and the Middle Ages (Hanzelyová, Kuzma, Rajtár, 1995, p. 55; Kolníková, 2002; Rajtár, 2002, pp. 360-361, Figures 1-2). Hurbanovo lies $15 \mathrm{~km}$ north of the Danube, which in the Roman period formed the northern frontier of the Roman Province of Pannonia. Even though the area was close to border at the time, it still belonged to barbarian territory (Figure 1).

The rescue excavation in 2003 was limited to a sounding of $55 \times 30-35 \mathrm{~m}$ just below the planned building (Rajtár, 2004). It covered the area from the lower slope of the dune (altitude $121.1 \mathrm{~m}$ asl) to the depression (at $119.5 \mathrm{~m}$ asl), a rise of $1.5 \mathrm{~m}$. The archaeological situation in the sounding was complex (Figure 2). A network of (probably modern or late-medieval) parallel and criss-crossing ditches along with a layer, formed by the erosion of settlement debris accumulated during its long-term occupation, covered the unclear traces of settlement pits and other structures outlined in the subsoil. The earliest phase of occupation of the site within the sounding area dates to the Eneolithic. The infill of features 8 and 26 yielded distinctive pottery and other finds (e.g. a sledgehammer) of the earlier phase of the Baden culture, the so-called Boleraz Group (Němejcová-Pavúková, 1979). Feature 17 provided pottery and animal bone finds assigned to the Early Iron Age (Vekerzug Culture). The largest proportion of the uncovered features (11, 16, 23 in Figure 2) and the artefacts are from the Roman Period occupation of the site. The Middle Ages are represented by the remains of two sunken huts $(5,6)$ with finds dating to the $9^{\text {th }}$ and $11^{\text {th }}-12^{\text {th }}$ century AD.

\subsection{Excavation}

Pit no. 23 (Figure 3) was situated on the lower elevated western limit of the sounding, in the terrain sloping down towards the inundation depression. The area was wet, and since the excavations took place between the end of October and mid-November, the surface was often frozen to a depth of $10 \mathrm{~cm}$. The oval ground plan of the pit and its dimensions of $200 \times 180 \mathrm{~cm}$ and dark infill appeared at a depth of 30-40 $\mathrm{cm}$ from the present-day surface. Next to its eastern edge was a shallow oval pit of $50 \times 35 \mathrm{~cm}$ with brown infill (probably the bottom-most part of a post hole?). The southern half of feature no. 23 was excavated first. The upper $40 \mathrm{~cm}$ of the fill consisted of a dark grey-brown sandy layer with small pebbles (Figure 3.1). Artefacts retrieved by hand comprised a small number of ceramic fragments and an iron spur (Rajtár, 2004, pp. 292-294, Figures 113-115). Below was a 15-cmdeep layer of lighter colour, with small stones, fragments of
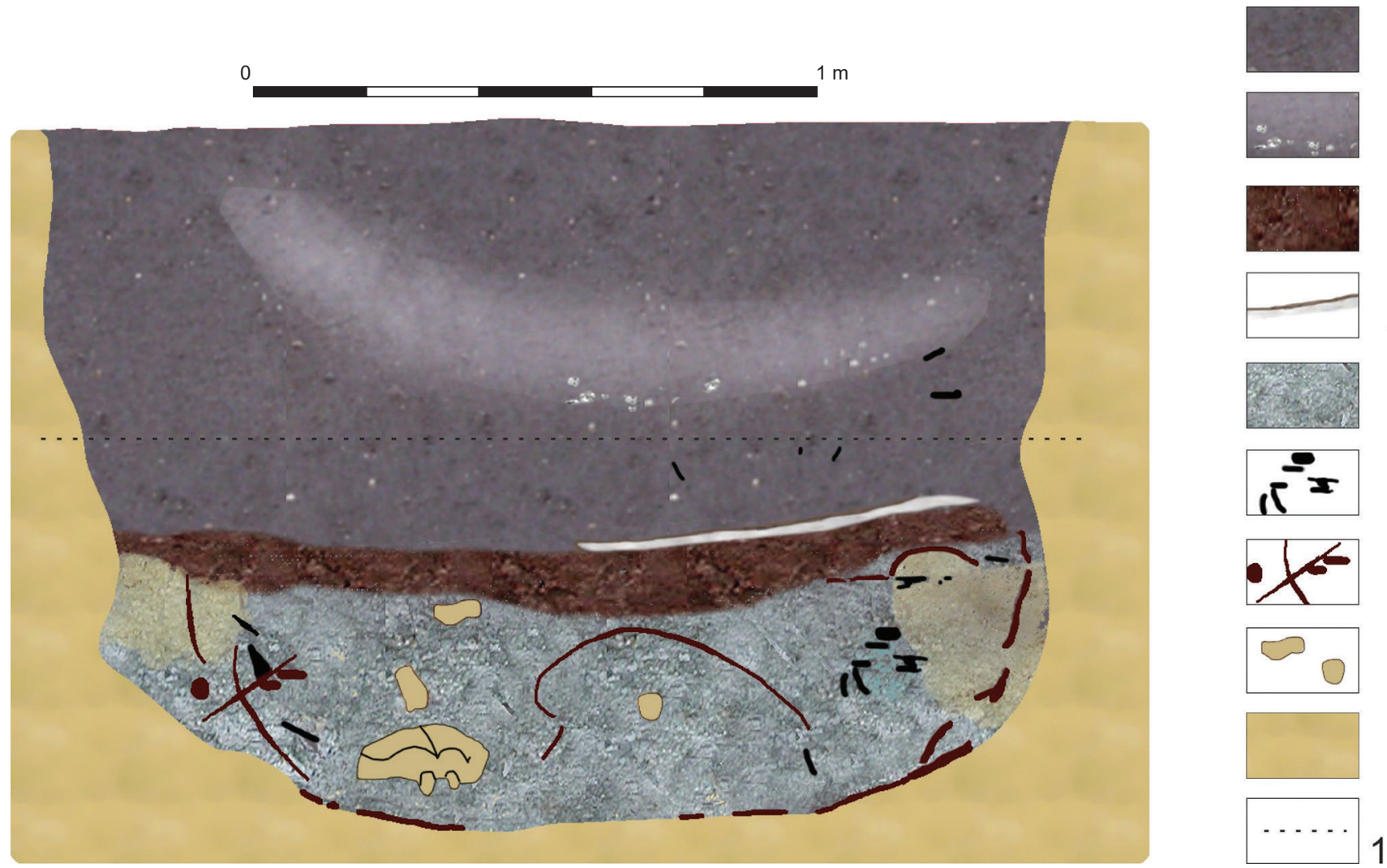

Figure 3. Hurbanovo-Štrkovisko; profile section of feature no. 23 from the excavation surface. Legend: 1 - sandy layer with small pebbles; 2 - layer with small stones; fragments of calcium concretions and daub; 3 - layer rich in organic material; 4 - ashy layer; 5 - silt; 6 - charcoal; 7 - waterlogged wood; 8 - animal bone; 9 - bedrock; 10 - ground water level. 


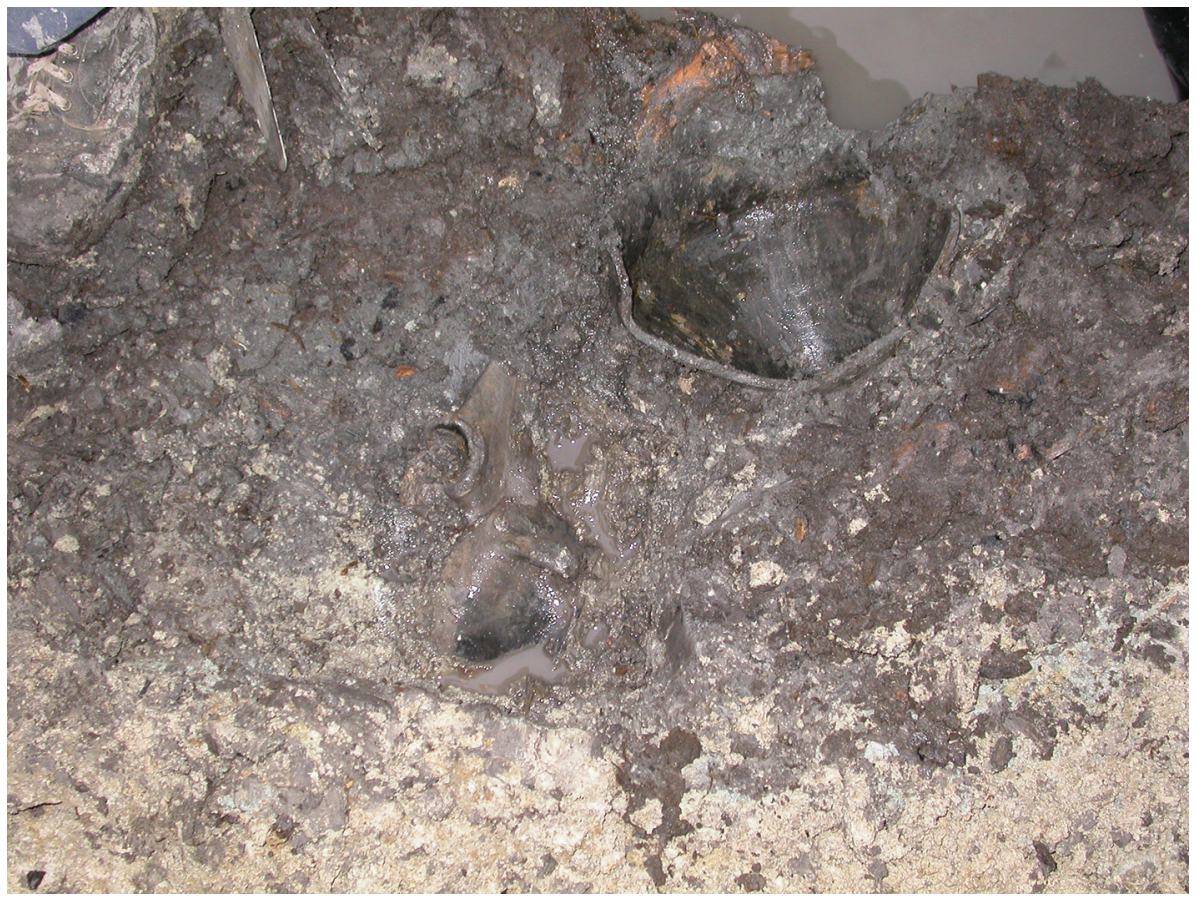

Figure 4. Hurbanovo-Štrkovisko; detail of the excavated layer ca $120 \mathrm{~cm}$ with the pottery and bones in situ.

calcium concretions and daub (Figure 3.2). It overlaid another dark grey-brown layer, which reached down to $80 \mathrm{~cm}$ and yielded a few larger daub fragments, stones, two fragments of bronze plate and some charcoal fragments. At the level of ca $70 \mathrm{~cm}$ from the excavation surface, the underground water started to flow into the feature (Figure 3.10). Next was a 5-10-cm-deep brown-red layer rich in organic material, the majority being probably partly-decomposed plant matter (Figure 3.3). In its eastern part, it was overlaid by a thin, light-grey "ashy" layer (Figure 3.4). Apart from the organic matter the brown-red layer also contained larger fragments of ceramic vessels, a well-preserved vessel with fibre, waterlogged wood, and animal bones (Figure 3.6, 3.7, 3.8 and Figure 4$)$. The constant inflow of the water and the absence of a proper pumping device made the excavation a challenging affair and disenabled the proper excavation, documentation and retrieval of finds. For this reason, part of the fill was taken in bulk and placed into large plastic bags. The inflowing water was drawn out by buckets. The remaining fill formed a 40-cm-deep, grey-yellow or greenish silt (Figure 3.5). Its upper part was "shovelled out" of the pit and searched for finds. From this were retrieved pottery, animal bones, charcoal and numerous wood fragments. The remaining fill was thus put into plastic bags for a later, moredetailed retrieval of finds and water flotation.

The obtained profile (vertical cross section) of the feature showed that the pit had perpendicular walls, slightlycurved in their lower part, and a flat bottom. Its depth was $180-190 \mathrm{~cm}$ from the modern terrain, and $150 \mathrm{~cm}$ from the level where it has been recognised. The cross-section revealed that the lower part of the walls, and probably also the bottom of the pit, were lined (?) with wood (branches) or some disentangled wooden construction (?). The excavation of the northern part of the feature was also complicated by the constant inflow of water. First, the topmost (more sandy) $70 \mathrm{~cm}$ of fill was taken out, and then, by hand, were retrieved from it ceramic fragments and larger pieces of daub. The lower, waterlogged fill layers (after drawing out water by buckets), were sampled in bulk and placed into plastic bags.

Unfortunately, the bulk samples were not numbered or labelled, and their order or spatial/contextual information was not recorded. Similarly, no labelling or contextualising has been performed for the recovered wood, animal bone, ceramic, daub or iron finds. All materials and samples have been treated in the field, brought to the laboratory and processed as if originating from a single-event context. Despite the clear archaeological evidence of at least three different layers (contexts/events), the individual samples had to be evaluated as one composite sample (sensu Pearsall, 2000 , p. 71), which, in a way, limits the interpretation of the results. All wooden finds, prior to the analyses, were treated in polyethylenglycol (PEG).

\section{Methods}

\subsection{Extraction and sorting of finds}

Processing of bulk sediment samples was performed during the winter of 2003 and 2004 in the laboratory. Each bag was opened and the finds - mostly waterlogged wood, but also animal bones and ceramic finds - were extracted by washing the sediment away. However, prior to this, a sediment sample of 5 litres was sub-sampled from each of the plastic bags. A combination of the manual methods of wet sieving and wash over was used to extract plant macro-remains, bones, molluscs, insects, and fish scales. To preserve fragile plant macro-remains the sediments were not dried out before the flotation (usually performed for the extraction of molluscs), 
but processed still wet. Firstly, a handful of sediment was put on a sieve column of $1 \mathrm{~mm}$ and $0.25 \mathrm{~mm}$ mesh sizes and sprayed with water until the majority of sediment dissolved and passed through the sieves. Organic finds caught in the sieve - seeds, fruits, wood, charcoal, mollusc remains, insects, small bones, and coprolites, with light or coarse sediment particles, were then decanted to a container with water. The process was then repeated until all sediment from the sample had been processed. The container with finds and remaining sediment was then stirred and slowly poured onto a $0.25-\mathrm{mm}$ sieve, so all the floating or submersed organic matter was caught on the sieve, whereas all the sediment (socalled heavy residue) stayed at the bottom of the container. The heavy residue was then again wet sieved through a $1-\mathrm{mm}$ sieve and checked for any remaining ecofacts and artefacts. These were collected and added to the "flot" fraction. The combination of these methods secured the recovery of all the floral and faunal remains present. The extracted material was originally stored in glass jars filled with distilled water, but when the screening of a sample under the microscope showed an absence of degradable remains (e.g. cereal pericarps) it was then dried out prior to further analyses.

The sorting of material from "flot" fractions into categories was undertaken under a binocular microscope Zeiss V8 with up to $\times 45$ magnification. All ecofacts were picked up using a fine paintbrush or a pair of delicate tweezers.

\subsection{Identification of taxa and quantification of finds}

Species identification of seeds, fruits and chaff remains was made under a Zeiss V8 binocular microscope with maximum $\times 60$ magnification. Taxa determination was based on a variety of available keys and atlases and was cross-checked with a modern seeds reference collection. For plant macro-remains, the number of finds for each sub-category such as apex, base, hilum, whole seed, half seed, was recorded and consequently the minimum number of individuals (MNI) was estimated. The number of identified specimens (NISP) is only given for fragmented cereal grains smaller than one quarter of a grain.

The waterlogged wood and charcoal fragments from the "flot" samples and hand-retrieved from the fill were determined under a microscope Zeiss Discovery V 12 a Zeiss Jenavert with reflected light and maximum magnification of $\times 250$. Small samples taken from waterlogged wood finds were dried up prior to microscopic analysis. Wood taxa identification is based on an examination of anatomic traits in transversal, tangential and radial sections. For charcoal and wood fragments, each find is counted as one (with the exception of one wooden post clearly broken into two parts).

Identification of molluses was made under a stereomicroscope Leica M205C with up to $\times 60$ magnification. For shells, apices were counted, but nonapical fragments of species otherwise unrepresented were also scored. For bivalves (such as Pisidium casertanum), the number of valves extracted was rounded up to the nearest even number and then halved. In each case, this gave the minimum number of individuals (MNI) present for each species (Meyrick, Preece 2001).
Insects, predominantly beetles, were identified using a streomicroscope Zeiss Jena 1 with up to $\times 100$ magnification. The identifiable remains, preferably pronota, elytra, heads and legs and their fragments were counted and their numbers mutually confronted to obtain the most probable MNI. For example, two legs and one remnant of elytrum of a species were taken as one individual, while three legs and two heads were taken as two individuals. However, for most samples a species was represented by only one find. The nomenclature of beetle names was adopted according to Jelínek (1993). Data on the ecology of species were taken from Reiter (1916), Šustek (2004) and Tesař (1957).

The animal bones were evaluated using the unaided eye and hand magnifier; anatomic and taxonomic identification, the assessment of age/sex, taking of measurements and recording of any bone modifications was performed (Behrensmeyer, 1978; Driesch, 1976; Kolda, 1936; Lyman, 1994; Reitz, Wing, 1999; Schmid, 1972; Silver, 1969). The age categories of cattle, pig and caprines were adopted from Peške (1994, pp. 308-309). The qualitative evaluation of represented skeletal elements referred to Uerpmann (1973). The results were quantified according to the number (NISP) and weight (WISP) of identified specimens and the minimum number of individuals (MNI). MNI was calculated on the basis of the most frequent element of the taxa, with reconsideration of the body side, and if available, information on the age and sex. Shoulder height of dog was estimated on the basis of the internal dimensions of the cranial cavity (Chrószcz et al., 2007).

\subsection{Dating of the feature and its fill}

The archaeological dating of the Roman Period occupation phase of the site is based on the distinctive Germanic and Roman provincial pottery and an iron spur datable to the end of the $2^{\text {nd }}$ and first half of the $3^{\text {rd }}$ century AD (Rajtár, 2004, p. 147). Archaeologically, no intrusions of an earlier date or younger contaminants were present. The feature seemed to be a sealed Roman period context. However, among uncharred plant remains recovered from flotation samples, the seeds of Datura stramonium a neophyte species introduced to Europe from the New World were found in three different samples indicating possible contamination. In addition, the dating of some very well-preserved insect remains was also doubtful.

To ascertain the dating of seeds and insect remains, originally three samples representing different plant categories and preservations were selected: a charred grain of cultivated einkorn (Triticum monococcum); three uncharred seeds of carrot (Daucus carrota), a wild/cultivated plant; and an uncharred leg and head corner fragment of Copris lunaris, a beetle that has become almost extinct in modernday western Slovakia.

Two radiocarbon dates-HUR_19999(Poz-89254) obtained on the charred cereal grain (Triticum monococcum), and HUR_20010 (Poz-91716) from the uncharred beetle Copris lunaris - performed by accelerator mass spectrometry at the Poznań Radiocarbon Laboratory, support the archaeological dating of the fill (Figure 5). Regrettably, all three uncharred seeds of the carrot (Daucus carota) HUR_20000 (Poz-0) were 


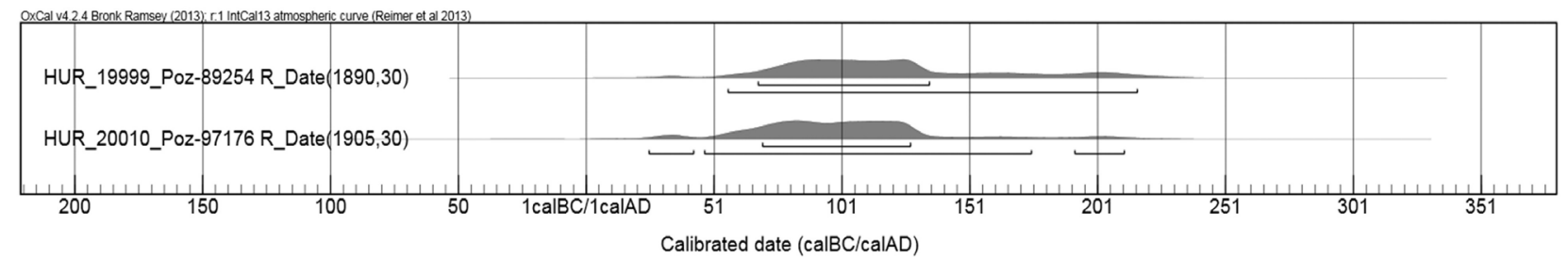

Figure 5. Hurbanovo-Štrkovisko; 1 - AMS radiocarbon dating of samples HUR 19999 - charred cereal grain (Triticum monococcum). 2 - HUR 20010 uncharred beetle fragment (Copris lunaris). Calibration in OxCal v. 4.2.4. (Bronk, Ramsey 2013), IntCal 13 (Reimer et al., 2013).

completely dissolved during the pre-treatment, and could not be dated. An uncharred seed of Datura stramonium HUR 19998 (Poz-98008) was selected for AMS dating for three reasons. Firstly, to verify whether this species, frequently present in charred (as well as uncharred) archaeological samples in eastcentral Europe, is not an apophyte (native to Europe) and indeed indicates contamination of the archaeobotanical samples. Secondly, despite strong archaeological reasoning for an uncontaminated fill, to demonstrate that the archaeobotanical samples were contaminated. Thirdly, the species is very robust, therefore it was hoped that a single Datura seed would contain a sufficient amount of datable carbon. As expected, the dating of Datura proved to be of a modern date and with very specific values of carbon ( $186.83 \pm 0.49 \mathrm{pMC})$ indicating its assimilation around 1963-64 (prof. Tomasz Goslar of Poznan Radiocarbon Laboratory pers. comm.) It is therefore clear that seeds of Datura stramonium: i.) indicate, in general, contamination of any archaeological context; ii.) show that, in Hurbanovo, the seeds do not originate from the present-day vegetation surrounding the excavation, but from the seed-bank which has accumulated within the ploughing horizon during cca the last century; iii.) reflect careless excavation technique (trampling of excavated sediment with muddy shoes) and use of an inappropriate sampling method (collection of samples from a non-cleaned surface) in the recovery of the archaeobotanical samples.

\section{Results}

\subsection{Seeds and fruits}

Almost 2990 seeds and fruits were identified to 139 species or other categories of plant taxa, originating from 85 genera and 28 families (Table 1). The charred remains are dominated by cultivated plants, mostly cereals (331 records, 18 taxa), and the waterlogged remains by wild taxa (2465 records, 106 taxa).

\subsubsection{Cereals and pulses}

All finds of cereals and pulses, except for two damaged cereal grains, are preserved in a charred form. The most common, yet relatively not numerous, are cereal grains of hulled barley (Hordeum vulgare) and spelt wheat (Triticum spelta). They are followed by millet (Panicum miliaceum), bread wheat (Triticum aestivum), emmer ( $T$. dicoccum), einkorn (T. monococcum) and rye (Secale cereale). Due to bad preservation or the high degree of fragmentation, many finds of wheat grains could not be further determined. Present, but extremely rare, are seeds of oat and two-grained einkorn. The chaff remains are dominated by the spikelets of einkorn, which even outnumber the einkorn grains. Pea (Pisum sativum) and lentil (Lens culinaris) are the only recorded pulses.

\subsubsection{Oil and fibre plants, vegetables, aromatics and medicinal plants}

The oil and fibre plants are represented by waterlogged seeds of hemp (Cannabis sativa). Both finds of flax seeds (Linum spp.), one charred and one waterlogged, are most probably from wild and not from cultivated species. The seeds of (possible) vegetables and/or aromatics - carrot (Daucus carrota), parsnip (Pastinaca sativa), black mustard/cabbage (Brassica $\mathrm{cf}$. nigra/campestris), dill (Anethum graveolens) and catmint (cf. Nepeta cataria) were all preserved only in a waterlogged state.

The seeds of the wild and cultivated varieties of carrot and parsnip cannot be distinguished. Both are known, from written sources, to have been used in the Roman cuisine (André, 1981, pp. 17-18). As the wild varieties of both species are native to the grassland communities of the region, it is not clear whether the recovered finds represent wild (i.e. not utilised) or cultivated and consumed plants. Dill, black mustard/cabbage and catmint are not native to the area, thus most probably represent introduced and cultivated plants. The seeds of domesticated apple (Malus domestica) and the grape vine (Vitis vinifera) are also from non-native, introduced (and locally?) cultivated fruits. The wood of those species that might be seen as evidence of local cultivation has not been detected in the wood or charcoal assemblage. Raspberry (Rubus cf. idaeus) could have been cultivated, but also could have been gathered from the wild.

The finds of waterlogged seeds of dill, mustard/cabbage and catmint, but also parsnip, from Hurbanovo, are the first or earliest records of these taxa from archaeological contexts from the territory of Slovakia. Seeds of cultivated grape vine and domesticated apple (though determined only as pear/ apple; Pyrus/Malus) are known from the Roman fortress of Iža (Hajnalová, Rajtár, 2009) situated on the Danubian Limes, ca $15 \mathrm{~km}$ south of Hurbanovo. However, the Iža finds originate from contexts dated to a later phase of the Roman Period and thus they are younger than the finds from Hurbanovo.

The presence of charred seeds of apple and raspberry might be seen as direct evidence of their handling-storing and/or consumption and consequent discard into fires and settlement refuse. 
Table 1. Hurbanovo-Štrkovisko; plant macro-remains. Legend: D - dry soils; W - wet soils; * - plants also occurring in arable land; ** - plants also occurring in arable land.

\begin{tabular}{|c|c|c|c|c|}
\hline & \multicolumn{2}{|c|}{ Charred } & \multicolumn{2}{|c|}{ Uncharred } \\
\hline & MNI & ubiquity & MNI & ubiquity \\
\hline \multicolumn{5}{|l|}{ Cereal grains } \\
\hline Hordeum vulgare L. & 23 & 8 & - & - \\
\hline Triticum spelta $\mathrm{L}$. & 22 & 7 & - & - \\
\hline Triticum dicoccum Schrank ex Schübler & 16 & 3 & - & - \\
\hline Triticum aestivum $\mathrm{L}$. & 16 & 7 & - & - \\
\hline Panicum miliaceum $\mathrm{L}$. & 16 & 8 & - & - \\
\hline Triticum monococcum $\mathrm{L}$. & 15 & 5 & - & - \\
\hline Secale cereale $\mathrm{L}$. & 10 & 4 & - & - \\
\hline Triticum cf. dicoccum & 5 & 2 & - & - \\
\hline Avena sp. & 3 & 3 & - & - \\
\hline Triticum monococcum two-grain & 1 & 1 & - & - \\
\hline Triticum sp. & 40 & 8 & - & - \\
\hline Triticum/Hordeum & 9 & 4 & 1 & 1 \\
\hline Cerealia indet $($ frag $<1 / 4)$ & 101 & 6 & - & - \\
\hline \multicolumn{5}{|l|}{ Cereal chaff } \\
\hline Triticum monococcum L. (sf) & 24 & 4 & 1 & 1 \\
\hline Triticum dicoccum Schrank ex Schübler (gb) & 4 & 3 & - & - \\
\hline Triticum monococcum/dicoccum $(\mathrm{gb})$ & 2 & 2 & - & - \\
\hline Triticum monoccoum/dicoccum (ri) & 1 & 1 & - & - \\
\hline Triticum spelta L. (gb) & 2 & 1 & - & - \\
\hline Ceralia indet. (ri) & 4 & 1 & - & - \\
\hline Cerealia (straw internodium) & 11 & 3 & - & - \\
\hline \multicolumn{5}{|l|}{ Pulses } \\
\hline Lens culinaris $\mathrm{L}$. & 2 & 2 & - & - \\
\hline Pisum sativum L. & 1 & 1 & - & - \\
\hline cf. Pisum sativum (frag) & 1 & 1 & - & - \\
\hline
\end{tabular}

\begin{tabular}{|c|c|c|c|c|}
\hline \multicolumn{5}{|l|}{ Oil and fibre plants } \\
\hline Cannabis sativa $\mathrm{L}$. & - & - & 27 & 6 \\
\hline \multicolumn{5}{|l|}{ Vegetables, spices, medicinal } \\
\hline Daucus carota $\mathrm{L}$ & - & - & 5 & 5 \\
\hline Pastinaca sativa $\mathrm{L}$. & - & - & 2 & 1 \\
\hline Brassica nigra/campestris & - & - & 2 & 1 \\
\hline Anethum graveolens L. & - & - & 1 & 1 \\
\hline cf. Nepeta cataria L. & - & - & 1 & 1 \\
\hline
\end{tabular}

\begin{tabular}{|c|c|c|c|c|}
\hline \multicolumn{5}{|l|}{ Cultivated Fruits } \\
\hline Vitis vinifera $\mathrm{L}$ & - & - & 3 & 2 \\
\hline Rubus cf. idaeus L. & 1 & 1 & 1 & 1 \\
\hline Malus domestica L. & 1 & 1 & - & - \\
\hline \multicolumn{5}{|l|}{ Wild woody plants with edible fruits or nuts } \\
\hline Sambucus ebulus L. & - & - & 259 & 15 \\
\hline Sambucus nigra L. & - & - & 2 & 2 \\
\hline Sambucus sp. & - & - & 5 & 2 \\
\hline Carpinus betulus L. & 1 & 1 & - & - \\
\hline Rubus caesius L. & - & - & 1 & 1 \\
\hline Humulus lupulus L. & - & - & 1 & 1 \\
\hline Rosa canina L. & - & - & 1 & 1 \\
\hline \multicolumn{5}{|l|}{ Wild herbaceous plants (* also weed) } \\
\hline \multicolumn{5}{|l|}{ Weeds of fields and gardens } \\
\hline Arenaria serpyllifolia $\mathrm{L}$. & 1 & 1 & 9 & 2 \\
\hline Bromus secalinus L. & 1 & 1 & - & - \\
\hline Bupleurum rotundifolium $\mathrm{L}$. & - & - & 4 & 3 \\
\hline cf. Echinochloa crus-galli (L.) P. B. & 1 & 1 & 1 & 1 \\
\hline Cirsium arvense (L.) Scop. & - & - & 1 & 1 \\
\hline
\end{tabular}


Table 1. Hurbanovo-Štrkovisko; plant macro-remains. Legend: D - dry soils; $\mathrm{W}$ - wet soils; * - plants also occurring in arable land; ** - plants also occurring in arable land. (Continuation)

\begin{tabular}{|c|c|c|c|c|c|}
\hline & & & & & \\
\hline & Convovulus arvensis L. & 1 & 1 & 1 & 1 \\
\hline & Fallopia convovvulus (L.) Á. Löve & 1 & 1 & 10 & 6 \\
\hline & Fumaria officinalis L. & - & - & 3 & 3 \\
\hline & Lamium amplexicaule $\mathrm{L}$. & - & - & 1 & 1 \\
\hline & Metha arvensis L. & - & - & 2 & 2 \\
\hline & Myosurus minimus L. & - & - & 29 & 4 \\
\hline & Polycnemum arvense $\mathrm{L}$. & 42 & 1 & 100 & 11 \\
\hline & Polygonum aviculare $\mathrm{L}$. & - & - & 302 & 17 \\
\hline & Polygonum cf. aviculare L. & - & - & 8 & 2 \\
\hline & Rumex acetosella $\mathrm{L}$. & - & - & 2 & 2 \\
\hline & Setaria viridis/verticillata & 4 & 3 & 92 & 12 \\
\hline & Stachys anпua (L.) L. & - & - & 2 & 2 \\
\hline & Stachys arvensis (L.) L. & - & - & 4 & 3 \\
\hline & Thlaspi arvense L. & - & - & 3 & 2 \\
\hline & Urtica urens L. & - & - & 30 & 4 \\
\hline & Vicia cf. tetrasprema (L.) Schreber & 1 & 1 & - & - \\
\hline Field & argins and hedges & & & & \\
\hline $\mathrm{D}$ & Agrimmonia eupatoria $\mathrm{L}$. & 1 & 1 & 1 & 1 \\
\hline & Bromus arvensis L. & 1 & 1 & - & - \\
\hline & Carex divulsa/praecox & 1 & 1 & 11 & 4 \\
\hline & cf. Cynosurus cristatus L. & 2 & 1 & - & - \\
\hline & Linum sp. & 1 & 1 & 1 & 1 \\
\hline W & Lycopus europaeus L.* & - & - & 48 & 9 \\
\hline & Meadows and other grasslands & - & - & - & - \\
\hline & Bromus sp.* & 1 & 1 & - & - \\
\hline $\mathrm{D}$ & Carduus cf. nutans L. & - & - & 3 & 1 \\
\hline W & Carex panicea $\mathrm{L}$. & - & - & 5 & 3 \\
\hline & cf. Festuca sp. & 2 & 1 & - & - \\
\hline W & cf. Poa palustris L. & 1 & 1 & - & - \\
\hline $\mathrm{D}$ & Cichorium intybus L.* & - & - & 2 & 1 \\
\hline W & Cirsium palustre (L.) Scop. & - & - & 5 & 2 \\
\hline & Cirsium/Carduus* & 1 & 1 & 17 & 4 \\
\hline $\mathrm{D}$ & Galeopsis ladanum L.* & - & - & 1 & 1 \\
\hline $\mathrm{D}$ & Hypericum perforatum $\mathrm{L}$. & - & - & 27 & 6 \\
\hline & Chenopodium/Atriplex* & 1 & 1 & 1 & 1 \\
\hline & Medicago cf. lupulina L.* & 2 & 2 & - & - \\
\hline & Plantago lanceolata $\mathrm{L} . *$ & - & - & 1 & 1 \\
\hline W & Potentilla anserina $\mathrm{L}$. & - & - & 4 & 1 \\
\hline $\mathrm{D}$ & Potentilla argentea $\mathrm{L}$. & 4 & 2 & 105 & 9 \\
\hline $\mathrm{D}$ & Potentilla argentea/arenaria & - & - & 7 & 3 \\
\hline & Potentilla reptans/argentea* & - & - & 34 & 6 \\
\hline & Ranunculus acris L. & - & - & 3 & 3 \\
\hline $\mathrm{D}$ & Ranunculus bulbosus L. & - & - & 1 & 1 \\
\hline $\mathrm{W}$ & Ranunculus repens/lanuginosus* & - & - & 3 & 2 \\
\hline W & Ranunculus sceleratus L. & - & - & 5 & 1 \\
\hline $\mathrm{D}$ & Salvia pratensis L.* & - & - & 1 & 1 \\
\hline W & Silaum silaus (L.) Sch. et Thell. & - & - & 1 & 1 \\
\hline & Silene vulgaris (Moench) Garcke & - & - & 1 & 1 \\
\hline $\mathrm{D}$ & Teucrium chamaedrys L.* & 1 & 1 & 115 & 11 \\
\hline W & Thalictrum lucidum/flavum & - & - & 5 & 4 \\
\hline W & Verbena officinalis $\mathrm{L}$. & - & - & 402 & 14 \\
\hline W & Xanthium strumarium L.* & - & - & 4 & 1 \\
\hline & Ruderals (** also fallow land) & - & - & - & - \\
\hline & Balota nigra L.* & 1 & 1 & 28 & 6 \\
\hline $\mathrm{D}$ & Cerastium arvense L.* & - & - & 1 & 1 \\
\hline & Datura stramonium L.* & - & - & 3 & 3 \\
\hline
\end{tabular}


Table 1. Hurbanovo-Štrkovisko; plant macro-remains. Legend: D - dry soils; W - wet soils; * - plants also occurring in arable land; ** - plants also occurring in arable land. (Continuation)

\begin{tabular}{|c|c|c|c|c|c|}
\hline \multirow[t]{2}{*}{$\mathrm{W}$} & Hyoscyamus niger L.** & - & - & 60 & 11 \\
\hline & Chenopodium album aggr.* & 22 & 3 & 210 & 16 \\
\hline \multirow[t]{4}{*}{ W } & Chenopodium hybridum L.* & - & - & 21 & 9 \\
\hline & Lamium cf. album L.* & - & - & 1 & 1 \\
\hline & Lepidium campestre (L.) R. Br.** & - & - & 1 & 1 \\
\hline & Malva neglecta Wallr.* & - & - & 1 & 1 \\
\hline \multirow[t]{4}{*}{ W } & Rumex crispus/obtusifolius* & - & - & 3 & 3 \\
\hline & Solanum nigrum L.** & - & - & 3 & 3 \\
\hline & Stellaria media (L.) Vill.* & - & - & 2 & 1 \\
\hline & Urtica dioica $\mathrm{L} . *$ & - & - & 14 & 5 \\
\hline \multicolumn{6}{|c|}{ Water banks } \\
\hline W & Alisma cf. plantago-aquatica $\mathrm{L}$. & 1 & 1 & 2 & 1 \\
\hline W & Carduus crispus L. & - & - & 5 & 3 \\
\hline W & Galeopsis tetrahit L.* & 1 & 1 & 4 & 4 \\
\hline $\mathrm{W}$ & Persicaria lapthifolia (L.) Delarbre* & - & - & 16 & 3 \\
\hline W & Potamogeton sp. & - & - & 2 & 2 \\
\hline W & Scirpus cf. sylvaticus & - & - & 1 & 1 \\
\hline $\mathrm{W}$ & Schoenoplectus lacustris/tabernemontanii & - & - & 26 & 3 \\
\hline $\mathrm{W}$ & Typha sp. & - & - & 8 & 3 \\
\hline \multicolumn{6}{|c|}{ Woodlands } \\
\hline $\mathrm{W}$ & Ajuga reptans L.* & - & - & 1 & 1 \\
\hline \multirow[t]{2}{*}{$\mathrm{W}$} & Atropa bella-donna L.* & 1 & 1 & 2 & 1 \\
\hline & Carex cf. hirta L.* & - & - & 113 & 13 \\
\hline W & Lamium cf. maculatum L. & - & - & 6 & 2 \\
\hline $\mathrm{W}$ & Lamium maculatum $\mathrm{L}$. & - & - & 3 & 1 \\
\hline W & Physalis alkekengi $\mathrm{L}$. & - & - & 4 & 2 \\
\hline \multicolumn{6}{|c|}{ Unknow or various habitats } \\
\hline & Polygonum/Persicaria* & - & - & 16 & 4 \\
\hline & Galium sp. * & 2 & 1 & - & - \\
\hline & Amaranthus sp. & - & - & 1 & 1 \\
\hline & Arctium sp.* & - & - & 6 & 3 \\
\hline & Atriplex sp. * & - & - & 4 & 3 \\
\hline & Dianthus sp. & - & - & 1 & 1 \\
\hline & Ranunculus sp. & - & - & 6 & 3 \\
\hline & Rumex sp. & - & - & 4 & 4 \\
\hline & Sinapis sp. & - & - & 4 & 1 \\
\hline & Appiaceae & - & - & 1 & 1 \\
\hline & Carduus sp. & - & - & 3 & 3 \\
\hline & Carex spp. & - & - & 3 & 2 \\
\hline & Lamiaceae & - & - & 8 & 3 \\
\hline & Lamium sp. & - & - & 17 & 5 \\
\hline & Ranunculaceae & - & - & 2 & 1 \\
\hline & Silenaceae & - & - & 1 & 1 \\
\hline & Silene sp. & - & - & 2 & 2 \\
\hline & Solanaceae & - & - & 2 & 2 \\
\hline & Stachys sp. & - & - & 4 & 2 \\
\hline & Stachys/Galeopsis & - & - & 1 & 1 \\
\hline & Stellaria $\mathrm{sp.}$ & - & - & 1 & 1 \\
\hline & Teucrium sp. & - & - & 1 & 1 \\
\hline & Viola sp. & - & - & 4 & 3 \\
\hline & Asteraceae & 1 & 1 & 5 & 4 \\
\hline & Cyperaceae & 1 & 1 & 2 & 1 \\
\hline & Indeterminata (seed) & 60 & 7 & 119 & 11 \\
\hline & Indeterminata (bud) & 6 & 2 & 21 & 4 \\
\hline Total & & 353 & 21 & 1040 & 21 \\
\hline
\end{tabular}




\subsubsection{Fruits of woody plants}

Species of this group have edible fruits which hypothetically might have been gathered and consumed. Preserved by charring there is only single nut of hornebeam (Carpinus betulus). The rest of the finds of fruits of woody plants such as hop (Humulus lupulus), rose (Rosa canina), dewberry (Rubus caesius) and elderberries (Sambucus ebulus, S. nigra, $S$. sp.) had been preserved only by waterlogging. Rose and dwarf elderberry are plants of open or semi-open habitats. Hornbeam is a (forest) tree and black elderberry, dewberry and hop grow in a variety of habitats, but they withstand shade, and they are often found in the forest understory or in ruderalized shaded stands.

Cultivation and/or consumption of these fruits and nuts, similar to the other above-mentioned "useful" wild plants preserved in waterlogged form in Hurbanovo, is feasible, but due to the nature of the archaeological context and studied sediment, impossible to prove. They could have grown in the proximity of the feature and their remains may have been deposited naturally in the forming sediments.

\subsubsection{The wild herbs and grasses}

Most of the finds (93\%) and taxa $(76 \%)$ of this group (2363 specimens, 109 taxa) were preserved by waterlogging. In the charred sub-assemblage, eight taxa are common weeds of fields or gardens (Arenaria serpylifolia, Bromus secalinus, Convolvulus arvensis, cf. Echinochloa crus-galii, Polycnemum arvense, Setaria viridis/verticillata and Vicia cf. tetrasperma) and ten taxa occur primarily in other open habitats, but also grow as weeds in fields (Balota nigra, Bromus sp., Cirsium/Carduus, Chenopodium album aggr., Chenopodium/Atriplex, Medicago cf. lupulina, Galium sp. and Atropa bella-donna). It is probable that these taxa accompanied crops in the fields and came to the settlement with the harvest to be processed, and if not consumed, discarded and burned. The seven species (Agrimmonia eupatoria, Alisma plantago-aquatica, Bromus arvensis, cf. Cyonurus cristatus, cf. Festuca sp., cf. Poa palustris and Potentilla argentea) are today not associated with arable land, but originate in grassland communities of wet or dry meadows, pastures, hedges or screes. The way of their arrival to the settlement and the reason for their carbonisation is unclear. Hypothetically, they could have been harvested and brought with the hay or other forms of animal fodder to the settlement, where they came in contact with fire and were charred.

Uncharred waterlogged seeds and fruits can be classified into the same categories. There are twelve taxa of common weeds of fields or gardens (Bupleurum rotundifolium, Cirsium arvense, Fumaria officinalis, Lamium amplexicaule, Mentha arvensis, Myosurus minimus, Polygonum aviculare, Rumex acetosella, Stachys annua, Stachys arvensis, Thlaspi arvense, and Urtica urens) and twenty-one taxa of primarily other open habitats, but possible arable weeds (Ajuga reptans, Amaranthus sp., Arctium sp., Atriplex sp., Carex cf. hirta, Cerastium arvense, Cichorium inthybus, Galeopsys ladanum, Chenopodium hybridum,
Lamium cf. album, Malva neglecta, Persicaria lapathifolia, Plantago lanceolata, Polygonum/Persicaria, Ranunculus repens/lanuginosus, Rumex crispus/obtusifolius, Salvia pratensis, Solanum nigrum, Stellaria media, Uritica dioica and Xanthium strumarium). There are three taxa of field margins and fallow land (Lycopus europeaus, Potentilla reptans/argentea and Datura stramonium - a supposed neophyte plant), four species of dry or drying grassland biotopes (Carduus cf. nutans, Hypericum perforatum, Potentilla argentea/arenaria and Ranunculus cf. bulbosus) and eight species of wet meadows, pastures or other open stands (Cirsium palustre, Carex panicea, Potentilla anserina, Ranunculus sceleratus, Silaum silaus, Thalictrum lucidum/flavum and Verbena officinalis). Ranunculus acris and Silene vulgaris occur in both wet and dry grasslands. Hyoscyamus niger, Lepidium campestre, Physalis alkekengi and Lamium maculatum occur almost exclusively in stands of ruderal vegetation or on disturbed land, and the latter two also in woodland. Four species (Scirpus cf. sylvaticus, Schoenoplectus lacustris/tabernemontanii, Typha sp., Carduus crispus L. and Potamogeton sp.) are associated with water or wetland biotopes.

\subsection{Charcoal and waterlogged wood}

The charcoal assemblage (Table 2) is dominated by oak (Quercus sp.), present almost in every sample. Other taxa are found in small quantities and in less than half of the samples. Among the relatively more numerous are maple (Acer sp.), hazel (Corylus avellana) and poplar/willow (Populus/Salix). With the same frequency, but lower in numbers are Pomoidae, a taxon group which includes a wide variety of species with edible fruits (e.g. apple, pear, hawthorn, serviceberry or mountain ash), difficult or impossible to distinguish in the charred material. Other taxa are less common.

The most common identified taxa in the waterlogged wood (Table 3 ) is also oak (82\%). Other taxa like Pomoidae, Populus/Salix, Fraxinus, Ulmus and Betula each comprise less than $5 \%$ of the assemblage. (198 finds of wood, 2 bark chips and 5 stems of flowering plants).

The wood finds can be divided into two major technological groups: 1) timber, such as posts or planks with rectangular section (19), and waste from their manufacture (86); and 2) round-in-section wood items such as stakes (14), used probably vertically, poles (66) used probably horizontally, and stakes/poles (14), all with either a circular or semicircular cross-section. None of the finds from either category represent a complete object. It is unclear if they were broken before deposition in the pit or during the excavation.

The number, diameter and width of annual tree-rings indicate that posts or planks were manufactured from trunks of older wood by longitudinally splitting in radial and/or tangential planes (Figure 6). Two longitudinally-split artefacts with sharpened and fired tips represent the bottom parts of wooden posts (e.g. Figure 7: 1-3). The original function of other finds from this group (e.g. Figure 7: 4) is unclear. The origin of the pieces of woodworking waste (wood chips, Figure 8: 4-6) is also impossible to assess. 
Table 2. Hurbanovo-Štrkovisko; wood charcoal.

\begin{tabular}{lcc}
\hline & NISP & Count \\
\hline Quercus sp. & 404 & 19 \\
Acer sp. & 22 & 8 \\
Corylus avellana & 11 & 5 \\
Populus/Salix & 10 & 4 \\
Pomoidae & 5 & 4 \\
Frangula alnus & 4 & 2 \\
Alnus sp. & 3 & 2 \\
Betula sp. & 3 & 2 \\
Fraxinus sp. & 3 & 2 \\
Tilia sp. & 1 & 1 \\
broad-leaved & 53 & 2 \\
coniferous & 1 & 1 \\
bark & 2 & 2 \\
\hline
\end{tabular}

Table 3. Hurbanovo-Štrkovisko; waterlogged wood. Legend: PP - posts or planks; MW - wood manufacturing waste; $\mathrm{S}$ - stakes; S/W - stakes/poles; $\mathrm{W}$ - poles and wattle.

\begin{tabular}{lcccccc}
\hline & PP & MW & S & S/W & Wattle & Total \\
\hline Quercus & 17 & 74 & 15 & 13 & 43 & 162 \\
Populus/Salix & 1 & 1 & 2 & & 1 & 5 \\
Fraxinus & & & 2 & & & 2 \\
Pomoidae & & & & 4 & 6 & 10 \\
Betula & & & & 1 & & 1 \\
Ulmus & & 2 & 1 & 1 & & 3 \\
broad-leaved & & 77 & 20 & 19 & 53 & 187 \\
\hline Total & 18 & & & & & \\
\hline
\end{tabular}

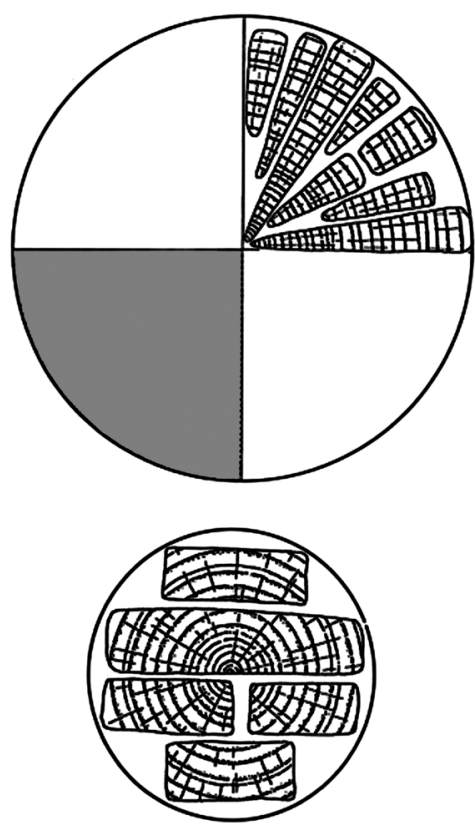

Figure 6. Diagram of ways of manufacturing wood planks by splitting. Radial splitting of large trunks (top), tangential splitting of small trees (bottom). After https://exarc.net/eurorea-3-2006/ea/ancient-wood-woodworking-andwooden-houses (Figure 4).
Poles and stakes are from short-lived one- to nine- (mostly three) year-old shoots. Both were in most cases partially or fully debarked. Stakes are made from more than five-yearold, rarely split, round wood pieces with diameters larger than $2.7 \mathrm{~cm}$ and sometimes with a sharpened tip (Figure 7: 5-7, Figure 8: 1-3). Poles (Figure 8: 7-8) represent whole or longitudinally-split branches or shoots (slats) mostly two to four years old and with diameters smaller than $2.7 \mathrm{~cm}$. Longitudinal flattening of the poles (Figure 8: 8) was recorded in 46 out of the 66 finds, and some were also slightly bent. The flattening and bending of the poles is most probably a result of the weaving of the wood used as wattle in building. Surprisingly, the majority of the wattle fragments were of oak (43), while other species used were rare, e.g. Pomoidae (6), elm (3) and indeterminate (3). The counted numbers of tree rings for oak, show that the wattle harvested were short lived, in the majority one- to three years old, branches or shoots (Figure 9). Rare terminal fragments of small twigs with buds (Figure 8: 9) are most probably only "naturfacts".

On 13 of the wooden artefacts (including six stakes and six poles/wattle), some remnants of piercing from metal nails were identified (Figure 10). On some finds more than one hole was detected. If present on finds with a cut end ("sharp" point), then the holes were situated within the cut or nearby. The best preserved holes were of different shapes - rectangular (7), triangular (2), oval (2) and unclear (4). Not a single nail was recovered, either inserted in the wood or loose. This, we believe, indicates that the wooden objects represent the dismantled part of an unknown wattle structure discarded in the pit and which is not a part of the original lining.

\subsubsection{Bark and bast}

There are also two specific artefacts of plant origin - a bundle of closer undetermined bast fibres recovered from the inside of a ceramic vessel (Figure 11) and a disintegrated container made of bark (Figure 12) identified macroscopically as birch (Betula sp.).

\subsection{Mammals, amphibians and fish}

The vertebrate assemblage consists of 194 specimens of bones, teeth, scales, and coprolites (Table 4). The majority of finds were retrieved by hand, while a smaller portion $(n=16$; $8.3 \%$ ) were sorted out from 15 flotation samples (Table 7 SOM). The identified specimens include six species, three genera and two orders of mammals and amphibians (Anura $\mathrm{sp}$.). The taxonomic identification of fish is still ongoing. Mammals are represented by cattle (Bos taurus), caprines (Ovis/Capra), pig (Sus domesticus), horse (Equus caballus), dog (Canis familiaris), red deer (Cervus elaphus), wild boar (Sus scrofa) and a weasel (Mustela sp.). The assessed minimum number of individuals is 22. The assemblage is dominated by the bones of large and medium-sized domesticated animals, and the proportion of wild taxa is small. The representation of wild animals, including small rodents, is noticeable only when considering the minimum number of individuals (Figure 13). 

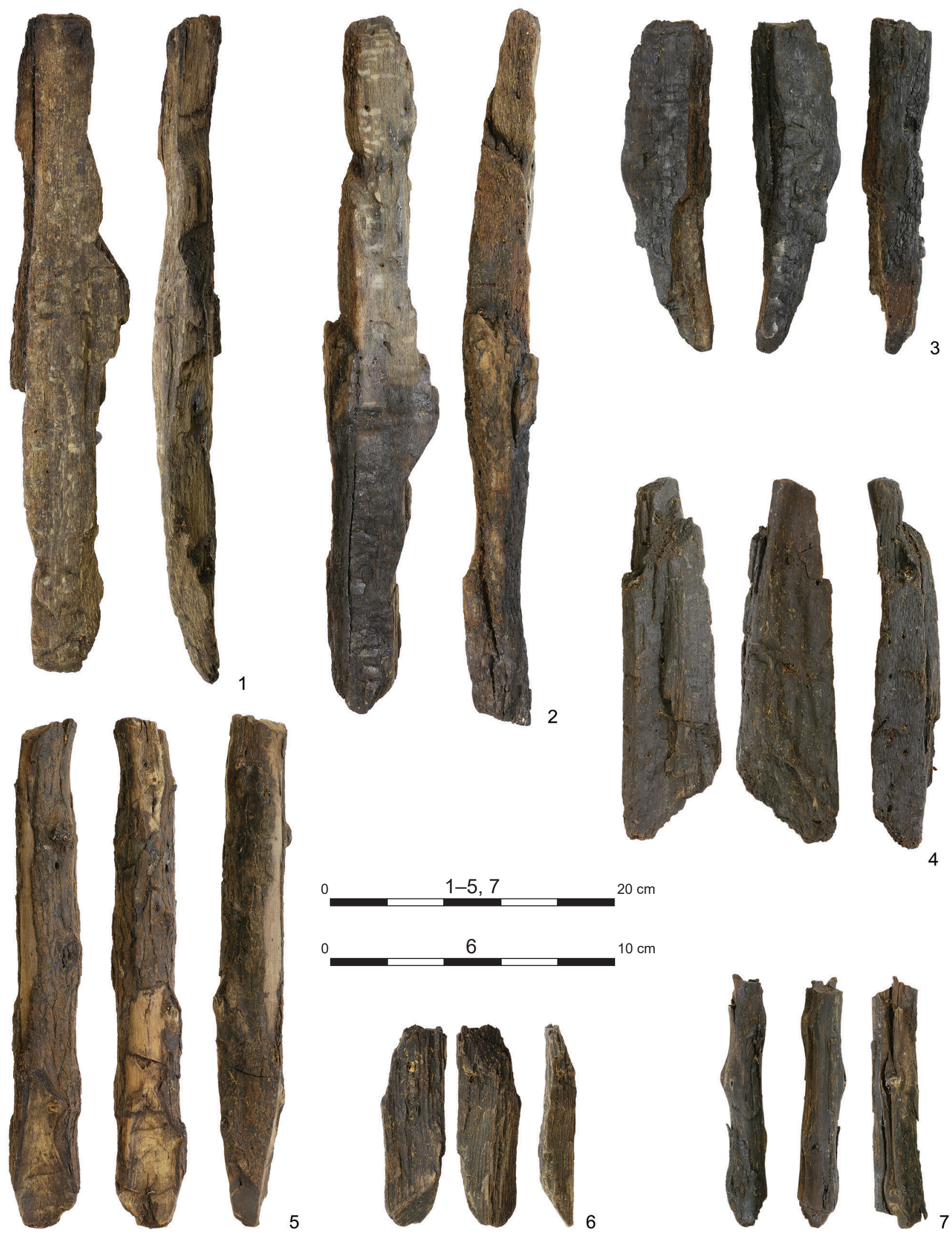

Figure 7. Hurbanovo-Štrkovisko; selection of wood artefacts - post and/or plank with $(1,3)$ and without fired tips $(2,4)$, unsplit stake with sharpened tip $(5,7)$, split stake with sharpened tip (6). 

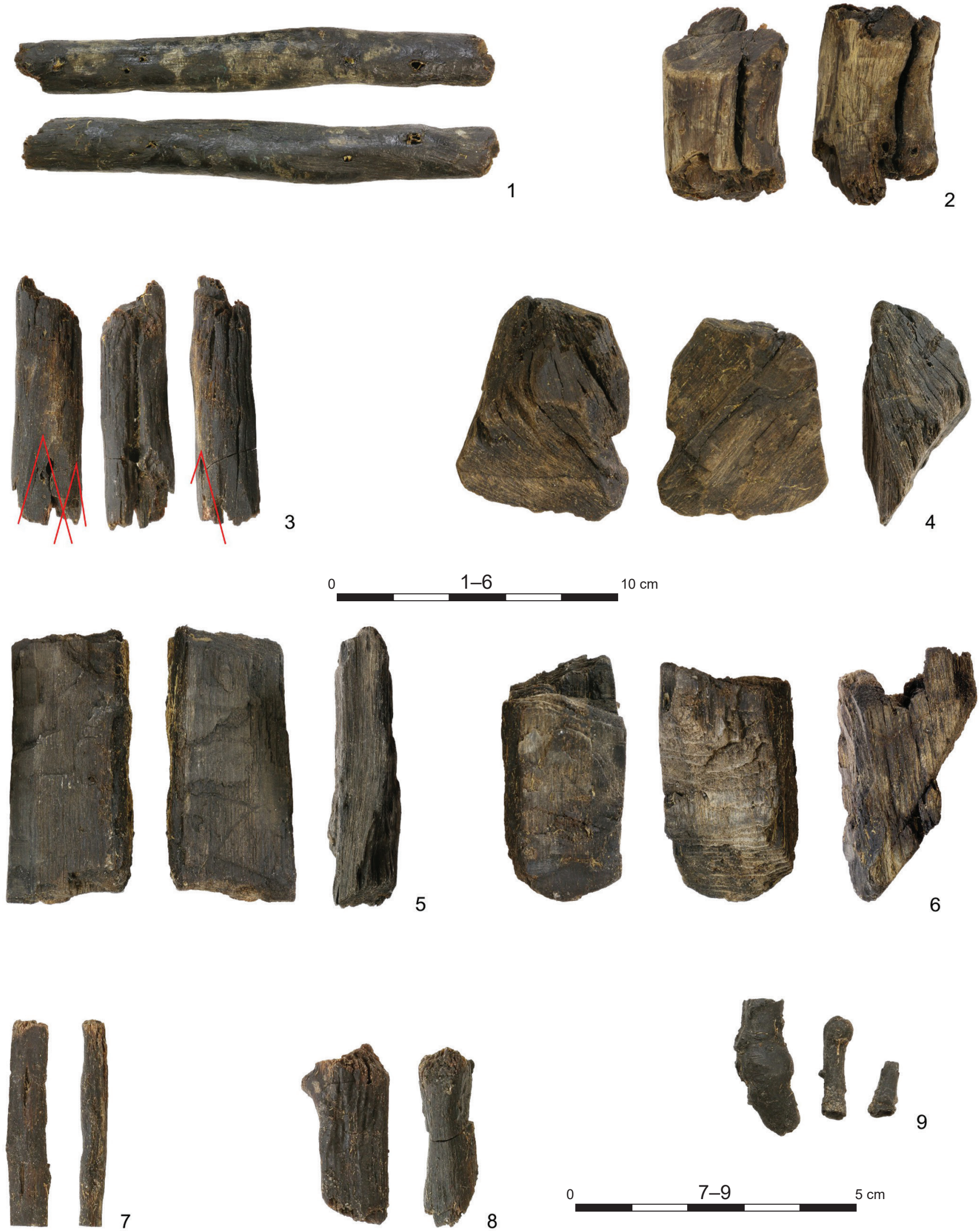

8

Figure 8. Hurbanovo-Štrkovisko; selection of wood artefacts - stakes without tip (1-3), wood-crafting waste (4-6), flattened and slightly bent pole/wattle $(7,8)$, twigs (9). 


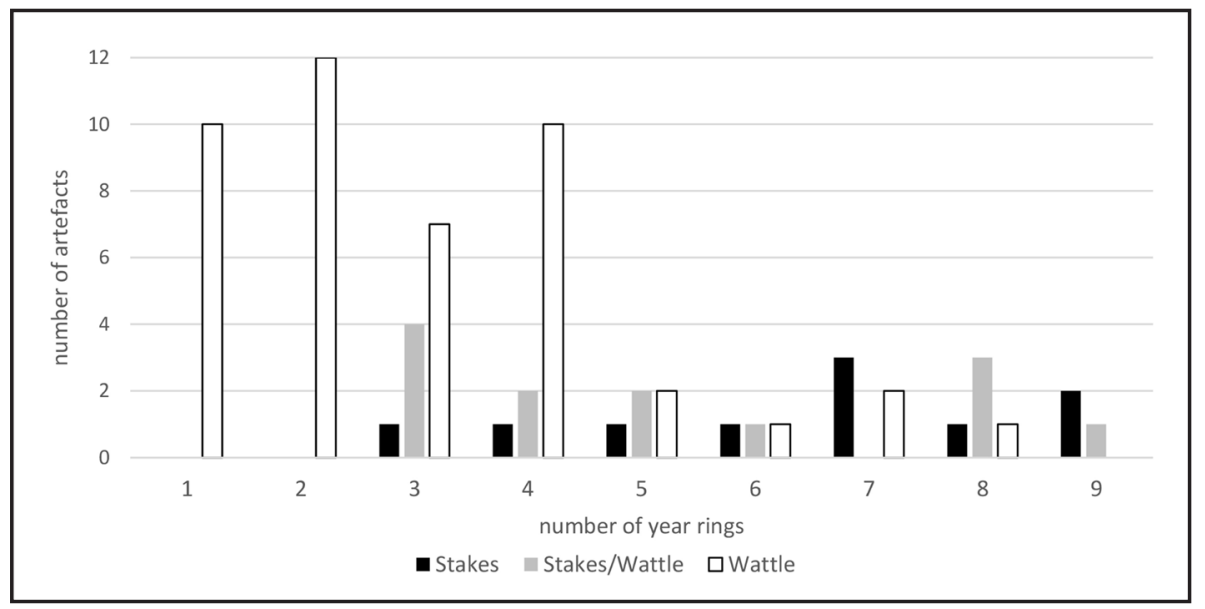

Figure 9. Hurbanovo-Štrkovisko; comparison of the age of wooden artefacts of different categories.

The collection of finds also includes some coprolites of a roundish or elliptical shape, which sometimes show a little tip at one end. Their colour is dark brown to black, and they are up to $1 \mathrm{~cm}$ long (Figure 14). The analysis of their content has not yet finished but some visible plant macro-remains suggest that they represent the faeces of small herbivores, most probably caprines.

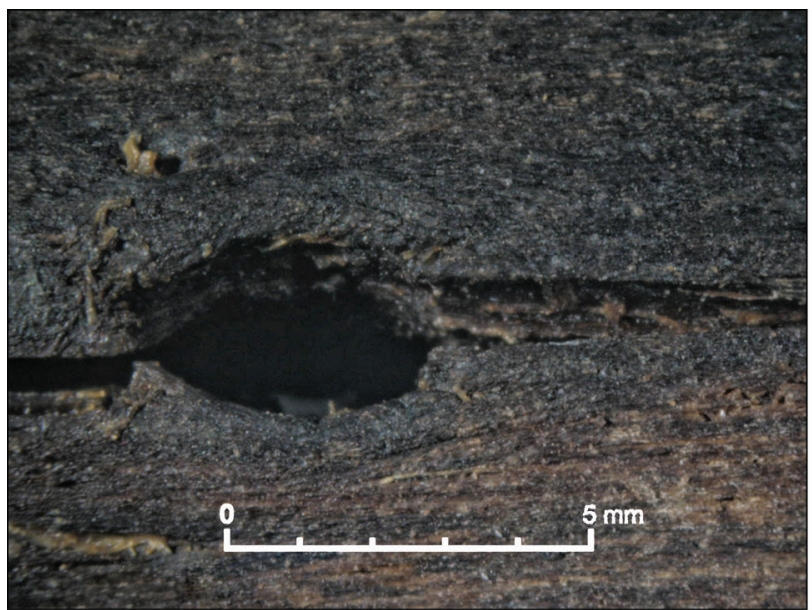

1

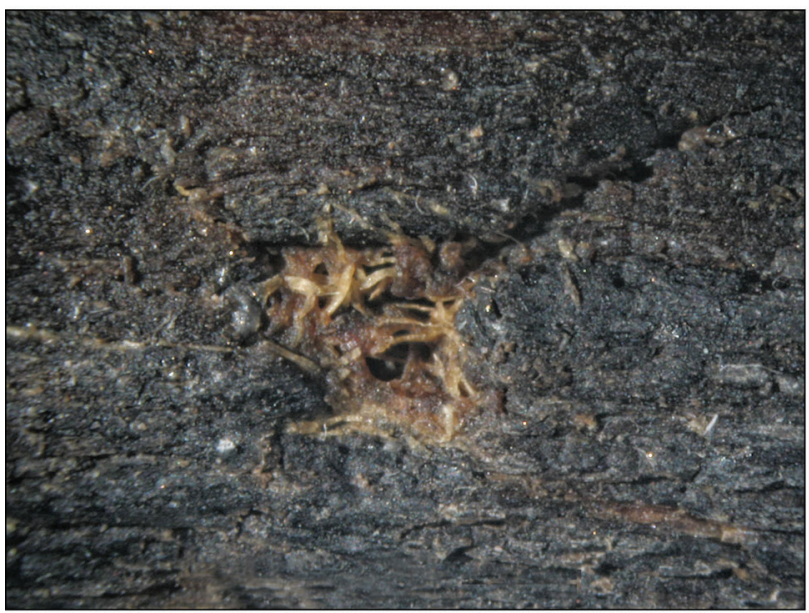

3

\subsubsection{Wild animals}

The wild boar and red deer both have extensive vertical and horizontal geographic distributions and wide habitat demands (Krištofík, Danko, 2012), with a preference for deciduous or mixed forest and open arable areas (Krištofík, Danko, 2012, pp. 496-497, pp. 525-526). Similar habitats are typical for the small carnivore Mustela sp. A weasel's
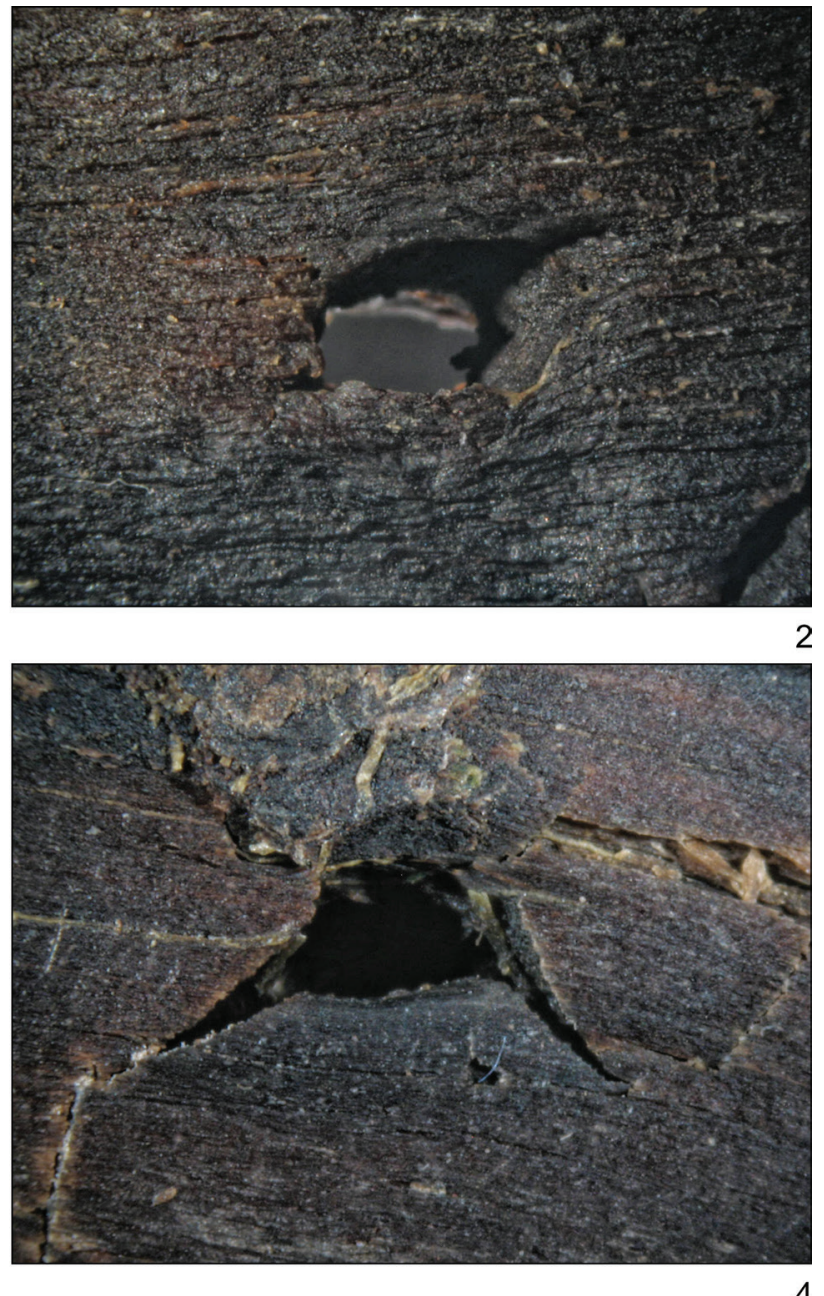

Figure 10. Hurbanovo-Štrkovisko; details of nail holes/insertions on the waterlogged wood. 

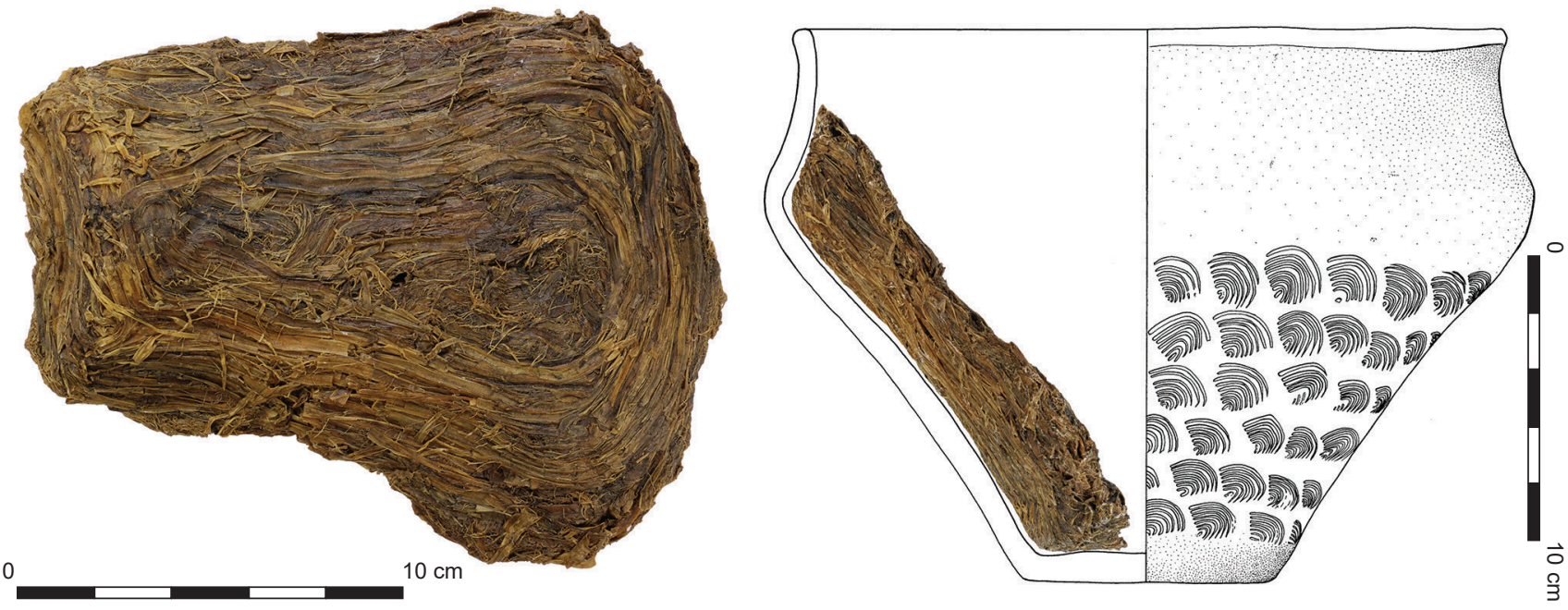

Figure 11. Hurbanovo-Štrkovisko; placement of the bast fibre bundle in the ceramic vessel (1), bast fibre bundle from the dorsal view (2).
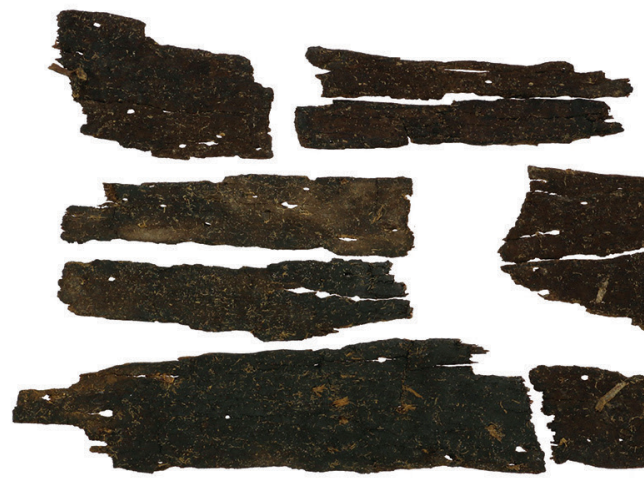

0

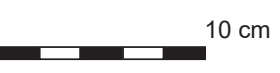

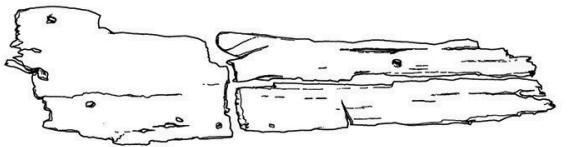
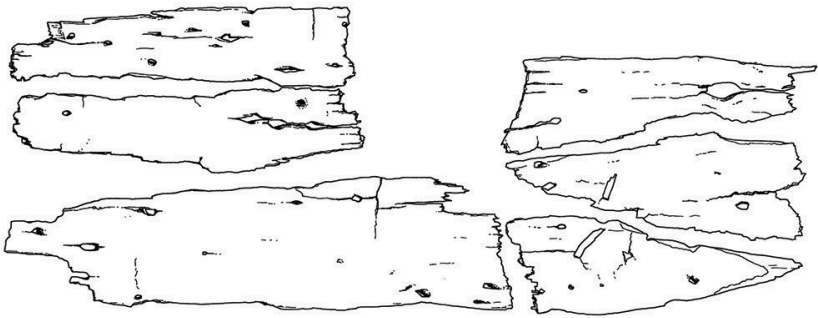

Figure 12. Hurbanovo-Štrkovisko; disintegrated birch bark artefact with small artificial openings.

Figure 13. Hurbanovo-Štrkovisko; identified animal taxa quantified after NISP, WISP and MNI.

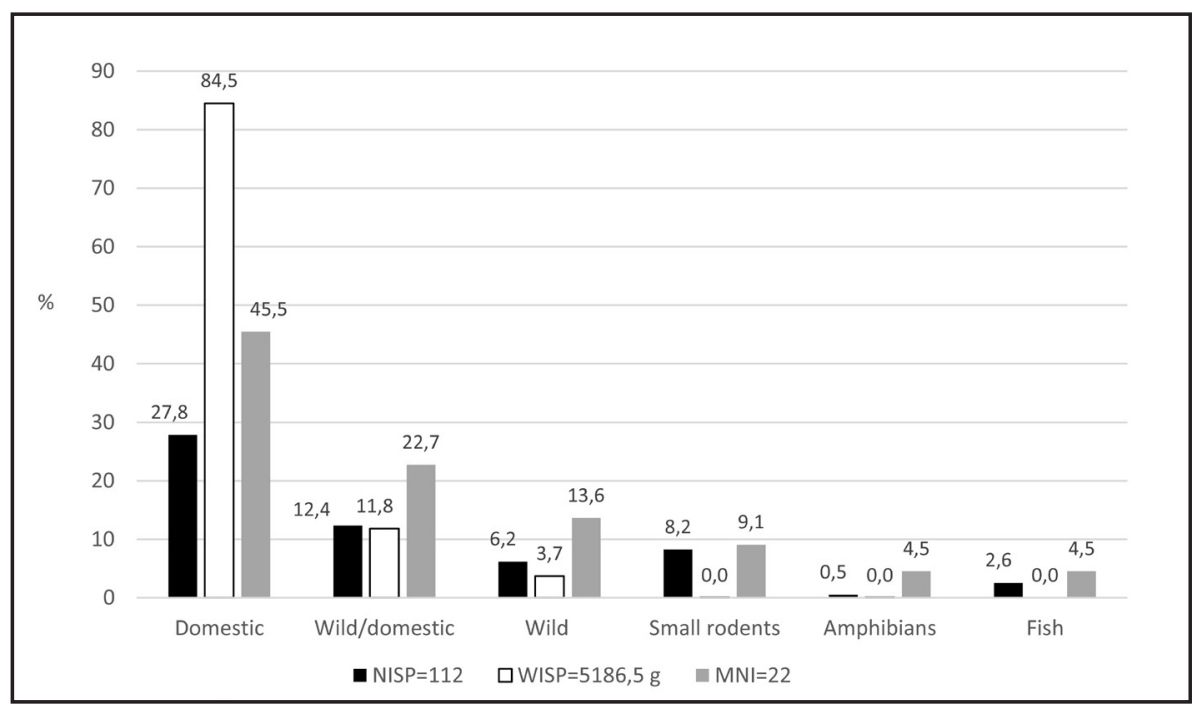

biotope encompasses mountain margins, pasture and arable lands, gardens, meadows, parks and human dwellings (Feriancová-Masárová, Hanák, 1965, p. 237). This animal is sporadically reported from archaeological contexts (Kyselý, 2005) and in Hurbanovo it has been retrieved thanks to the processing of subsamples by water flotation (sample no.
19998). We presume that all the identified specimens of a weasel represent a single individual, trapped in the pit, either naturally when attracted by organic waste or deposited there intentionally by humans. Similarly to that of frogs and small rodents, however, its intrusive character cannot be ruled out, as the weasel likes to inhabit mouse burrows. The 


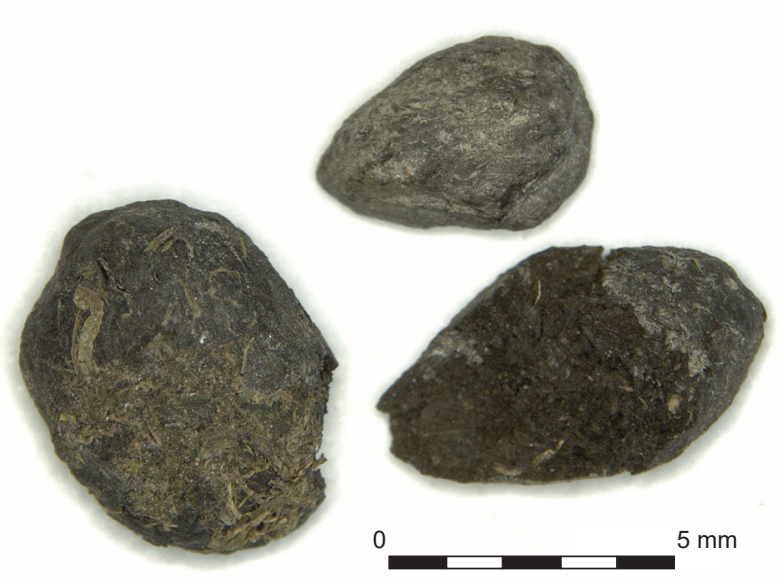

Figure 14. Hurbanovo-Štrkovisko; selection of coprolites sorted out from flotation sample no. 20010.

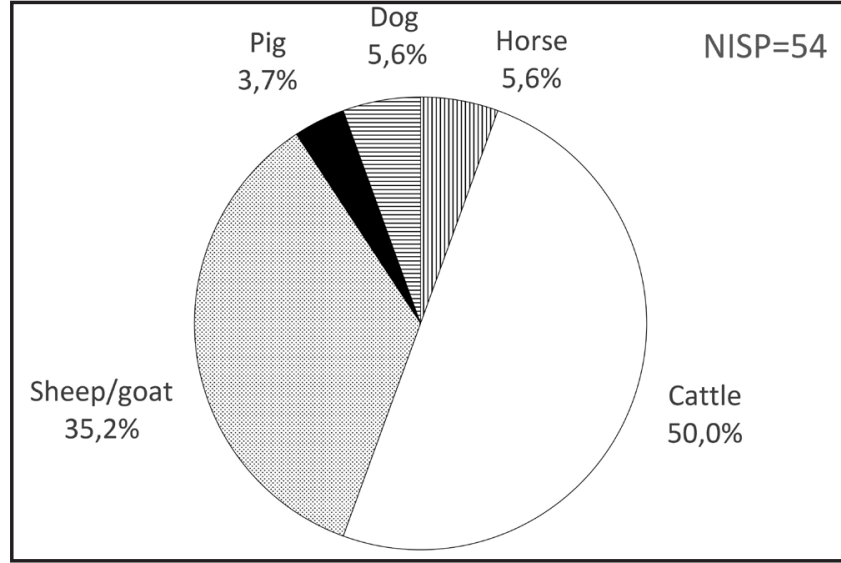

Figure 15. Hurbanovo-Štrkovisko; domestic species according to NISP.

Table 4. Hurbanovo-Štrkovisko; mammal, amphibian and fish remains quantified after NISP, WISP and MNI.

\begin{tabular}{|c|c|c|c|c|c|c|c|c|}
\hline Taxa & NISP & $\%$ of all & $\%$ of identified & WISP & $\%$ of all & $\%$ of identified & MNI & $\%$ of identified \\
\hline \multicolumn{9}{|l|}{ Domestic } \\
\hline Bos taurus & 27 & 13.9 & 24.1 & 3598.0 & 66.3 & 69.4 & 3 & 13.6 \\
\hline Ovis/Capra & 19 & 9.8 & 17.0 & 198.2 & 3.7 & 3.8 & 3 & 13.6 \\
\hline Equus caballus & 3 & 1.5 & 2.7 & 295.0 & 5.4 & 5.7 & 1 & 4.5 \\
\hline Canis familiaris & 3 & 1.5 & 2.7 & 202.1 & 3.7 & 3.9 & 1 & 4.5 \\
\hline Sus domesticus & 2 & 1.0 & 1.8 & 88.4 & 1.6 & 1.7 & 2 & 9.1 \\
\hline \multicolumn{9}{|l|}{ Wild } \\
\hline small rodent & 16 & 8.2 & 14.3 & 0.1 & 0.0 & - & 2 & 9.1 \\
\hline Mustela sp. & 9 & 4.6 & 8.0 & 1.8 & 0.0 & 0.0 & 1 & 4.5 \\
\hline Pisces & 5 & 2.6 & 4.5 & 0.6 & 0.0 & 0.0 & 1 & 4.5 \\
\hline Sus scrofa & 2 & 1.0 & 1.8 & 183.0 & 3.4 & 3.5 & 1 & 4.5 \\
\hline Cervus elaphus & 1 & 0.5 & 0.9 & 6.8 & 0.1 & 0.1 & 1 & 4.5 \\
\hline Anura & 1 & 0.5 & 0.9 & 0.0 & 0.0 & 0.0 & 1 & 4.5 \\
\hline \multicolumn{9}{|l|}{ Domestic/wild } \\
\hline medium mammal & 33 & 17.0 & - & 76.6 & 1.4 & - & - & - \\
\hline mammal & 21 & 10.8 & - & 18.0 & 0.3 & - & - & - \\
\hline large mammal & 12 & 6.2 & - & 142.1 & 2.6 & - & - & - \\
\hline Bos/Equus & 8 & 4.1 & 7.1 & 88.5 & 1.6 & 1.7 & 1 & 4.5 \\
\hline Sus sp. & 6 & 3.1 & 5.4 & 68.7 & 1.3 & 1.3 & 1 & 4.5 \\
\hline small mammal & 5 & 2.6 & - & 0.1 & 0.0 & - & - & - \\
\hline Bos/Bison & 4 & 2.1 & 3.6 & 95.2 & 1.8 & 1.8 & 1 & 4.5 \\
\hline Bos sp. & 3 & 1.5 & 2.7 & 306.9 & 5.7 & 5.9 & 1 & 4.5 \\
\hline Bos/Cervus & 3 & 1.5 & 2.7 & 53.6 & 1.0 & 1.0 & 1 & 4.5 \\
\hline Domestic & 54 & 27.8 & 48.2 & 4381.7 & 80.8 & 84.5 & 10 & 45.5 \\
\hline Wild & 34 & 17.5 & 30.4 & 192.2 & 3.5 & 3.7 & 7 & 31.8 \\
\hline Wild/domestic & 24 & 12.4 & 21.4 & 612.9 & 11.3 & 11.8 & 5 & 22.7 \\
\hline Identified & 112 & 57.7 & 100.0 & 5186.8 & 95.6 & 100.0 & 22 & 100.0 \\
\hline Unidentified & 79 & 40.7 & - & 236.8 & 4.4 & - & - & - \\
\hline coprolite & 7 & 3.6 & - & 1.2 & 0.0 & - & - & - \\
\hline Total & 194 & 100.0 & & 5424.8 & 100.0 & & 22 & 100.0 \\
\hline
\end{tabular}


representation of fish and amphibians clearly indicate water and humid biotopes in the vicinity of the site.

The red deer represents a single (male) antler fragment. It cannot be ascertained as to whether it originates from a hunted animal or is only a collected shed antler. Though, the recovered mandible and shoulder bone fragments (of unknown sex) of boar document a clear exploitation of this animal for meat. The wild boar and red deer are known to have been commonly hunted animals during this study period (Kyselý, 2005, p. 71, tab. 3). Our finds indicate that the animals were killed/died as adults. On the basis of the size and the archaeological context, we suggest that the bones of a weasel represent a partial skeleton - cranium, mandible, ribs, vertebrae and tibia of a single individual. Only a single fish bone has been identified as os articulare, thus representing the head part of the body. Together with unidentified fish scales, these finds may represent kitchen waste and food leftovers.

\subsubsection{Domestic animals}

The group of domestic mammals represent $48.2 \%$ of all specimens and is dominated by cattle and caprines (Figure 15). The minimum number of individuals of both taxa is equal, but it differs when considering the number (NISP) and especially weight of specimens (WISP). The predominance of cattle bone weight does suggest its importance in the diet, in terms of amount of meat. Domestic pig is represented by small numbers. However, the portion of unidentified wild/domestic (Sus sp.) specimens, by MNI the third most common taxa in the assemblage, must also be taken into consideration. In sum, the representation of the main domesticated animals in the assemblage cannot be really interpreted in terms of their input to the diet of the local population, not only due to the small size of the sample, but also due to the large portion of bones with unsecured identification (wild/domestic, large/medium mammals) that substantially skew the achieved quantified results. The representation of other taxa is scarce and varies according to the quantification method used (Table 4).

The cranial (30\% of NISP) and axial skeletal elements $(25 \%)$ prevail in the assemblage (Table $8-\mathrm{SOM})$. In cattle, the most represented are bones bearing a medium to low quantity of meat (category $\mathrm{B}=50 \%$ and $\mathrm{C}=30.8 \%$ after Uerpmann, 1973). This shows that the primary "butcher's" waste and elements with mid quality meat dominate the samples. Also, in caprines, the mid quality meaty elements are mostly represented (the sample size is too small for further interpretation). The age or sex data, which may provide information on the kill-off patterns of domestic livestock, are scarce. In cattle, the bones of juvenile as well as adult animals occurred. Epiphyseal data indicated the slaughtering age before ( 1 individual) and during the $2^{\text {nd }}$ year ( 1 individual) and meat exploitation. It is also suggested by the partiallypreserved neurocrania of cattle that belonged to a juvenile ( 1 individual) and young adults ( 2 individuals). The solitary horn-core find most probably belonged to a sub-adult cow. The dental data, however, proved the slaughtering of cattle in maturity ( 1 individual) and also indicated the keeping of cattle for their secondary products (labour, manure, milk, etc.). In caprines, slaughtering in between the $9^{\text {th }}$ and $12^{\text {th }}$ month (C category after Peške, 1994) and during the $3^{\text {rd }}$ or $4^{\text {th }}$ year ( $\mathrm{F}$ category) has been documented ( 1 individual). According to Uerpmann (1973, p. 316), the optimal age for meat production is 1-2 years, so we may assume that the older animal represented milk/wool production, or an ewe kept for producing young. In pigs, the slaughter of a subadult of 16-22 months (G category) and a young adult of 22 months ( $\mathrm{H}$ category) was observed, which fits the optimal age for meat production (1.5 year; Uerpmann, 1973). There was only one male pig identified. A well-preserved horse mandible belonged to a sub-adult animal in which the absence of the corner incisor (not erupted) indicates an age below $4.5 / 5$ years. The sex of this animal could not be stated, since the male canines are not erupted as is typical for such an age.

The morphometric data are scanty (Tables 7 and 8). However, the discovered skull fragments/parts and the horn-core did allow some information to be gained on the appearance of local livestock. The size, shape and position of the horn cores point to short-horned (brachyceros) cattle with the tong or clasp position of the horns (Kolda, 1936 , p. 559, Figure 175) in at least two individuals. The shoulder height of a dog individual has been assessed to approximately $35 \mathrm{~cm}$, comparable to that of a Beagle and other smaller medium-sized present-day breeds. The length of the first anterior phalanx of a horse $(\mathrm{GL}=88 \mathrm{~mm})$ indicates the presence of a "larger" individual (stallion/gelding?), slightly bigger than the average recorded for the local early medieval horses (Ambros, Müller, 1980, p. 142).

\subsubsection{Bone modifications}

Only nine specimens from the whole bone assemblage showed slight weathering and longitudinal cracking (after Behrensmeyer, 1978, stage 1, pp. 151-152, Figure 2:A) which indicates that most of the animal bones have been deposited into the pit shortly after carcass processing (interval 0-3 years after Behrensmeyer 1978, p. 157, Table 2) and quickly overlaid by other refuse. Some of the bones were partly stained from dark brown to black, most probably due to the surrounding humic and ashy sediment layer(s). A single rib fragment showed green staining from contact with a metal object, most probably a nearby artefact. Burning has been detected in a single fragment of cattle acetabulum (dark brown to black) suggesting contact with an open fire and impact of a temperature of circa $360-540^{\circ} \mathrm{C}$ (camp fires after Lyman, 1994, p. 386, Figure 9.9).

Only a small proportion of the investigated specimens were preserved complete $(3 \%)$ or at least three-quarters of the whole $(10.5 \%)$. Two partially-preserved calvarias of cattle and one nearly complete dog skull were preserved (Figure 16). Most probably these represent the primary refuse of carcass processing. However, non-economic reasons for its deposition cannot be excluded. The braincases of all were disrupted which leads to speculation of the exploitation of 

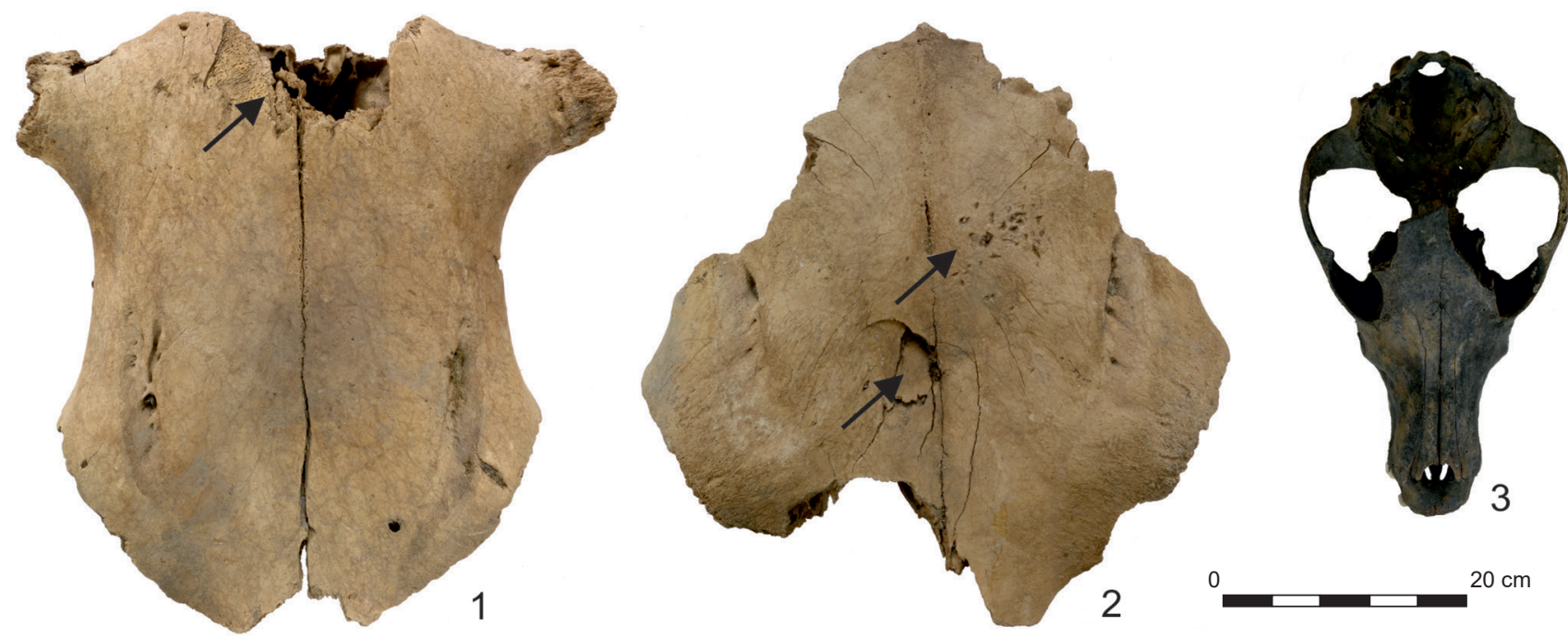

Figure 16. Hurbanovo-Štrkovisko; cattle and dog remains. 1 - cranium of a juvenile cow (calf) with brain case opening (arrow); 2 - larger plate of the frontal bone of an adult cow, with impression and point insertion marks (arrows); 2 - cranium of an adult/mature dog with destroyed brain case.

brain tissue. In the middle of the frontal bone of one cattle individual, an impression with circular/oval fracture lines and punctured from outside is seen (Figure 16: 2). Such depressions used to be related with peri-mortal injuries $(e . g$. Méniel, 2008, p. 144, Figure 116; Bartosiewicz, 2013, p. 85). A group of point insertion marks made by humans are located above the impression, but it is not clear if these marks are related to a peri- or post-mortal phase of the taphonomic history. The plate of the dog's skull braincase is destroyed, but similar to that of the cattle exemplars, it cannot be assumed if intentionally (Figure 16: 3). The animal shows strong dental surface abrasion, intravital canine and scissor fractures, and signs of chronic periodontitis that suggest a higher age and the feeding of the dog on hard tissue (bone waste?).

Some clear man-induced cut-marks were registered on the bones of cattle, caprines and pig, and include a variety of cuts and chops (17.5\% of NISP). The inflicted specimens show traces of secondary or tertiary butchery that represent traces of gross carcass portioning and body parts reduction into the smaller portions to fit in a pot or grill (see Rixon, 1989). In such cases it can be assumed that the main aim of manipulation with the animal bodies was the exploitation of meat and fat/marrow or the preparation of food. Leftovers had been thrown to dogs, as indicated by gnawing (19.3\% of NISP). Several cut marks occurred on the horse mandible too, indicating either portioning of the head or processing of the animal's skin.

\subsection{Molluscs}

A total of 480 fossilised shells of molluscs were analysed (461 land snail shells and 18 shells of freshwater molluscs) from 26 molluscan species, of which 22 species were confirmed as terrestrial and 4 as freshwater species (Table 5).

Among the terrestrial species, the land snails Vallonia costata $(42.8 \%)$ and Vallonia pulchella $(23.9 \%$ of the whole assemblage, Figure 17) dominated, indicating the presence
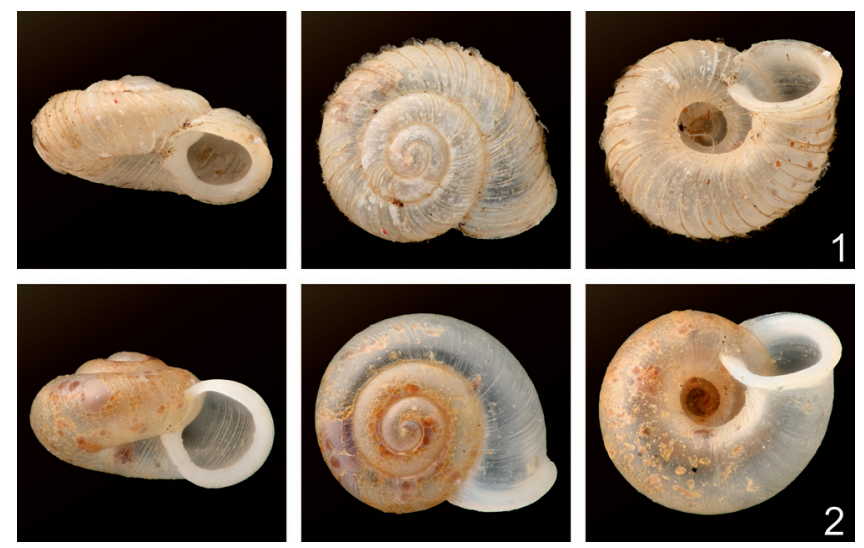

Figure 17. Hurbanovo-Štrkovisko; the most common land snail species: 1 -Vallonia costata; 2 - Vallonia pulchella. Photos not to scale (C) Jonas Roth.

of some form of open habitat from dry or wet meadows, open wetlands, steppe and other unspecified grassland, that transitions into marginal shrubland and open woodland. It also includes a forest-steppe of natural or man-made origin, such as pasture forests or sparse forest stands originated by selective cutting. The presence of short-turfed dry grassland, steppe or forest-steppe is indicated by the occurrence of the snail Chondrula tridens. From the paleoecological point of view, this is a significant species of the subcontinental steppe, linked with chernozem soils in the interstadials of the early glacial (Ložek, 1964). Currently, the species is very rare in the surveyed area. The assemblage also contains very small proportions of other open-country species such as Truncatellina cylindrica, Pupilla muscorum, Vertigo pygmaea and Oxychilus inopinatus.

The small proportion (8.4\%) of hygrophilic species, e.g. Carychium minimum, Succinea putris and Vertigo antivertigo, indicates the presence of very wet or waterlogged habitats. The aquatic molluscs, e.g. Anisus spirorbis, 
Table 5. Hurbanovo-Štrkovisko; the list of molluscs with ecological requirements indicated.

\begin{tabular}{|c|c|c|}
\hline Open habitats & no. ind. & ubiquity \\
\hline Vallonia pulchella & 110 & 14 \\
\hline Truncatellina cylindrica & 31 & 11 \\
\hline Pupilla muscorum & 21 & 6 \\
\hline Vertigo pygmaea & 3 & 1 \\
\hline \multicolumn{3}{|l|}{ Shrubland } \\
\hline Aegopinella minor & 3 & 1 \\
\hline Helix pomatia? & 1 & 1 \\
\hline \multicolumn{3}{|l|}{ Steppe or forest-steppe } \\
\hline Cochlicopa lubricella & 21 & 8 \\
\hline Chondrula tridens & 17 & 7 \\
\hline Oxychilus inopinatus & 3 & 2 \\
\hline Cepaea vindobonensis & 1 & 1 \\
\hline Euomphalia strigella & 1 & 1 \\
\hline \multicolumn{3}{|l|}{ Woodland } \\
\hline Vallonia costata & 197 & 14 \\
\hline Carychium tridentatum & 3 & 1 \\
\hline Clausiliidae juv. non det. & 2 & 1 \\
\hline Discus rotundatus/perspectivus & 1 & 1 \\
\hline \multicolumn{3}{|l|}{ Hygrophilous } \\
\hline Succinella oblonga & 22 & 6 \\
\hline Carychium minimum & 8 & 4 \\
\hline Cochlicopa lubrica & 4 & 2 \\
\hline Succinea putris & 2 & 1 \\
\hline Vertigo antivertigo & 2 & 2 \\
\hline \multicolumn{3}{|l|}{ Freshwater and/or other } \\
\hline Anisus spirorbis & 10 & 1 \\
\hline Nesovitrea hammonis & 8 & 1 \\
\hline Planorbis planorbis & 5 & 3 \\
\hline Pisidium casertanum & 2 & 1 \\
\hline Segmentina nitida & 1 & 1 \\
\hline Trochulus sp. & 1 & 1 \\
\hline
\end{tabular}

Planorbis planorbis and Segmentina nitida, are species of shallow swamps (even now, there are still the remnants of a terrestrialised water body), probably dry in a certain part of the year. The sample contained only 4 species of freshwater molluscs, represented only by 18 shells, an insufficient amount for an objective reconstruction of the surrounding aquatic landscape. We can conclude, however, that all species lived in stagnant, more or less densely-overgrown waters, which might have been temporary in character possibly drying out for a few weeks, or months from late spring to autumn.

\subsection{Insects}

Most of the identifiable remains of beetle bodies belong to species representing two very different ecological niches
Table 6. Hurbanovo-Štrkovisko; insect remains. Taxonomy, trophic relations, habitat and humidity preference (quantified after MNI and NISP). Legend: trophic relations (TR): D - (dryoftorous corticali)?; Ca carnivorous; $\mathrm{Co}$ - coprophagous; $\mathrm{Ph}$ - phytophagous; $\mathrm{Pa}$ - panthophagous; habitat preference (HaP): E - eurytopic (both forest and open habitats); $\mathrm{O}$ - open landscape species; $\mathrm{S}$ - saproxylic; humidity preference (HuP): 2 - xerophilous; 4 - mesohygrophilous; 5 - 6 moderately hygrophilous. The preference is characterized by a semi-quantitave scale ranging from 1 (strongly xerophilous) to 8 (extremely hygrophilous).

\begin{tabular}{lccccc}
\hline Taxon & NISP & MNI & TR & HaP & HuP \\
\hline Coleoptera & & & & & \\
Carabidae & & & & & \\
\hline Pterostichus melanarius & 2 & 1 & $\mathrm{Ca}$ & $\mathrm{E}$ & 5 \\
Pseudophonus calceatus & 2 & 1 & $\mathrm{~Pa}$ & $\mathrm{O}$ & 2 \\
Pterostichus niger & 2 & 1 & $\mathrm{Ca}$ & $\mathrm{E}$ & 6 \\
Pterostichus niger/melanarius & 1 & 1 & $\mathrm{Ca}$ & $\mathrm{E}$ & - \\
Ophonus azureus & 1 & 1 & $\mathrm{~Pa}$ & $\mathrm{O}$ & 2 \\
Harpalus zabroides & 1 & 1 & $\mathrm{~Pa}$ & $\mathrm{O}$ & 2 \\
Poecilus sericeus & 1 & 1 & $\mathrm{Ca}$ & $\mathrm{O}$ & 2 \\
Carabidae sp. & 1 & 1 & - & - & - \\
\hline Scarabaeidae & & & & & \\
\hline Onthophagus ovatus & 8 & 6 & $\mathrm{Co}$ & $\mathrm{O}$ & 4 \\
Onthophagus cf. taurus & 6 & 4 & $\mathrm{Co}$ & $\mathrm{O}$ & 4 \\
Copris lunaris & 3 & 3 & $\mathrm{Co}$ & $\mathrm{O}$ & 4 \\
Aphodius granarius & 2 & 1 & $\mathrm{Co}$ & $\mathrm{O}$ & 4 \\
Aphodius sp. & 2 & 2 & $\mathrm{Co}$ & $\mathrm{O}$ & 4 \\
\hline Chrysomelidae & & & & & \\
\hline Halticinae sp. & 1 & 1 & $\mathrm{Ph}$ & - & 4 \\
\hline Curculionidae & & & & & \\
\hline Dryophthorus corticalis & 1 & 1 & $\mathrm{D}$ & $\mathrm{S}$ & 4 \\
\hline Hymenoptera & & & & & \\
Formicidae & & & & & \\
\hline Lasius sp. & 1 & & & \\
\hline & & & & & \\
\hline
\end{tabular}

and trophic groups (Table 6, Figure 18). The first includes coprophagous species of the family Scarabaeidae. Among these, Copris lunaris is strictly bound to the faeces of big bovines and deer (Figure 19). Onthophagus ovatus, Onthophagus sp. (probably O. taurus), Aphodius granarius and Aphodius sp. are generalists, living and developing in the faeces of a wide spectre of herbivorous mammals and, in arable land, they are also attracted by freshly-applied manure or slurry. Onthophagus ovatus is also attracted, to a limited degree, by other decomposing organic materials, including cadavers or the contents of bird nests. Copris lunaris unambiguously indicates that cattle were pastured in the surroundings of the study site. Its occurrence has nothing to do with decaying organic wastes presumably deposited in the pit. In contrast, such organic waste could be sufficiently attractive for Onthophagus ovatus. This species is not strictly bound to faeces, but it also visits cadavers, or, on rare occasions, even accumulated decaying plants. However, it does not reproduce in such secondary substrates. 


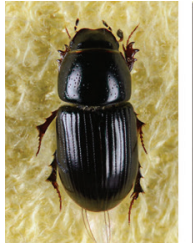

1

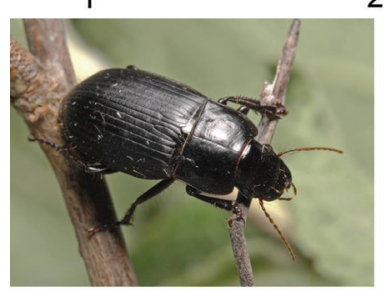

5

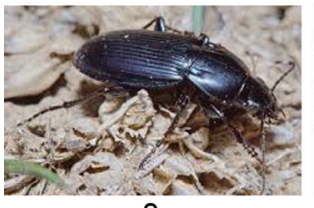

8

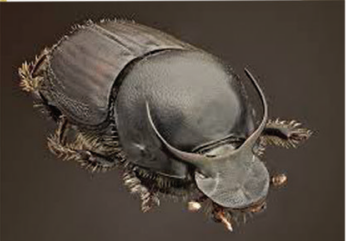

2

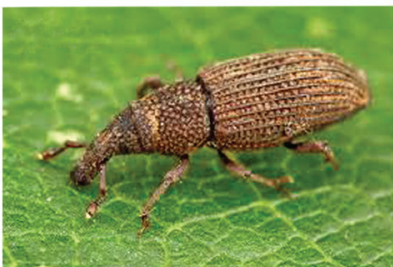

6

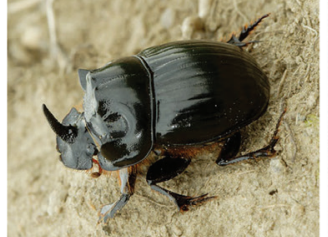

3

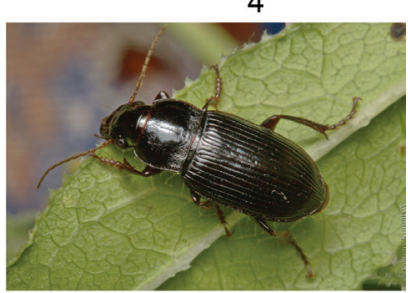

7

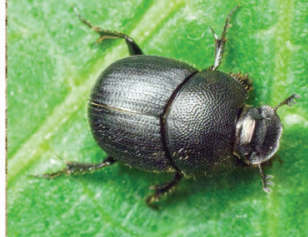

4

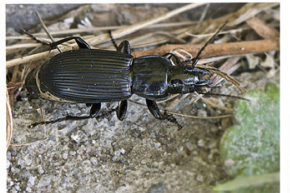

10

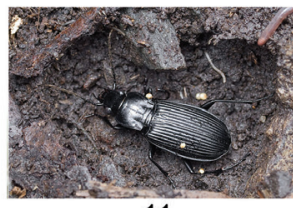

11
Figure 18. Hurbanovo-Štrkovisko; Beetles identified in the remnants of insects and their natural length: 1 - Aphodius granarius (4-5 mm); 2 - Onthophagus taurus (17-23 mm); 3 - Copris lunaris (6-12 mm); 4 - Onthophagus ovatus $(4.5-5.5 \mathrm{~mm})$; 5 - Harpalus zabroides (12.3-15.5 mm); 6 - Dryophthorus corticalis (3-4 mm); 7 - Harpalus calceatus (9.3-14.8 mm); 8-Poecilus sericeus (11.5-13.4); 9-Ophonus azureus (5.9-8.9 mm); 10 - Pterostichus melanarius (12.7-18.7 mm); 11 - Pterostichus niger (15.2-21.6 mm). The body sizes of dung beetles were taken from Tesař (1957); ground beetles from Hurka (1996) and of the weevil from Reitter (1916).

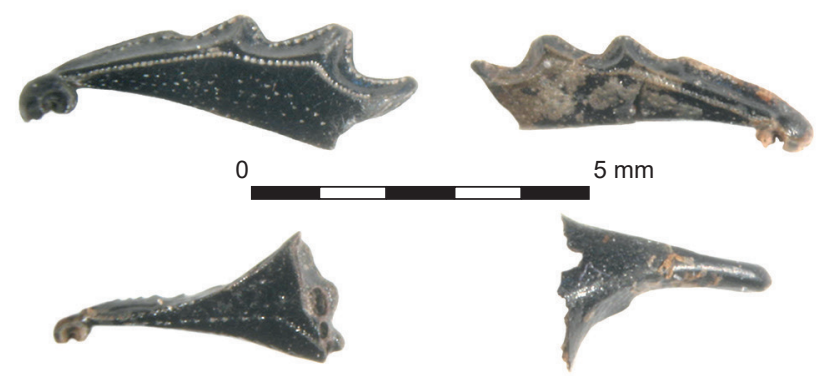

Figure 19. Remains of Copris lunaris, head corner, fore and middle tibia.

Only one remnant of an ant of the genus Lasius was found. These ants occur frequently in open landscape habitats, including ruderal and urban ones.

The second major group of beetles identified in the remains are Carabids (ground beetles). They represent the fauna of soil surfaces from various terrestrial habitats. The species composition at different localities depends predominantly on the degree of shade provided by tree vegetation, the geological substrate, and its humidity. The majority of recovered species are predators and scavengers. There are four pantophagous (omnivorous) species and only one species that is predominantly, or even exclusively, phytophagous (granivorous). Their remnants in the studied material belong to 6-7 species. All are typical representatives of open landscape, i.e. fields, meadows or ruderal areas, and have great dispersal power. The species Poecilus serriceus, Ophonus azureus and Harpalus calceatus are exclusively open landscape species. They are thermophilous and xerophilous. Ophonus azureus even tolerates habitats with discontinuous herbage vegetation. In contrast, Pterostichus melanarius and Pterostichus niger are eurytopic, more hygrophilous and also frequently occur in floodplain forests and humid habitats, where they form dynamically changing populations in accordance with momentary changes in humidity (Šustek, 1995). Normally they do not occur in meso-hygrophilous forests. By day, they hide in soil fissures, under stones and in litter. They probably indicate a ruderal site in the vicinity of a building, perhaps with some more-humid depression. They could also use the waste pit as a shelter.

Out of the species mentioned above, there were found remnants of an unidentified Halticid (Chrysomelidae), living on herbage vegetation and of a weevil (Curculionidae) Dryophorus corticalis representing the fauna of litter and decaying wood.

The above characteristics may fit the conditions in the studied site, but only under the precondition that the authenticity of these remnants of the studied strata can be guaranteed. However, especially in the Carabids, there exists a considerable possibility of recent contamination of the studied strata by individuals vertically migrating down into the soil, in particular during hibernation, or the passive transport of organic debris by water through the galleries of rodents and insectivores, deep cracks appearing in dry periods, or in the faeces of some insectivores (shrews, Sorex spp.). In the case of Copris lunaris, AMS dating confirmed that the two examined remains do originate from the Roman period (1905 $\pm 30 \mathrm{BP})$. Independently of this, the case for this species contaminating the examined strata by recent material in the last few decades is almost excluded, because of the extremely sporadic occurrence of this species in a landscape where regular pasturing has been eliminated. But the case for some medieval or early modern contamination is not excluded. However, this species is probably able to rapidly restore its populations as shown by an overpopulated deer park near Milovice and Bulhary in South Moravia, where a strong isolated population of Copris lunaris arose in spite of the fact that in other parts of Moravia, West Slovakia and Lower Austria this species almost does not occur.

Besides the remnants of insect bodies, the pieces of oak wood found in the pit were also examined for the presence of 
galleries or damage traces of xylophagous beetles (Anobiidae, Bostrichidae, Buprestidae, Cerambycidae, Lymexilonidae, Ptiniidae, Curculionidae - Scolytinae). However, there was found only one isolated, perfectly rounded opening of about $1 \mathrm{~mm}$ in diameter that might be interpreted as the gallery of an immature Anobiid larva. If this interpretation is correct, the position and isolation of the gallery indicates that the infestation of wood was negligible and the examined piece of the wood was attacked before its processing and use by the settlement inhabitants and deposition in the pit. Additionally, some irregular openings or shallow grooves, partly filled by soft organic matter, were found in the examined pieces of wood. Obviously they were not made by any xylophagous insects, but rather they resemble remnants of haustoria of the semiparasitic Loranthus (Loranthus europaeus), infesting specifically the oaks, or possibly also by the hyphae of some fungi (e.g. Armillaria ssp.).

\section{Discussion and conclusions}

The interpretation of the finds from waterlogged sediments and the functions of the archaeological structures from which they originate is a challenging task (e.g. Kenward, et al., 1980; Simpson, 2001). Crucial to this is the origin of the recovered finds (and an understanding thereof) and the processes that attributed to the formation of the fill (and being able to detect them).

\subsection{Taphonomy}

The finds of ceramics, bones and uncharred wood occurred together in the sediments. As no visible traces of bioturbation (such as earth rodent passages or burrows) were recorded in the waterlogged sediments of the fill, it is unlikely that these finds migrated horizontally or vertically through the compact sediment. Based on the relative chronology of the pottery, all the ceramic finds are therefore, without hesitation, dated to the early phase of the Roman period.

The dating and origin of the smaller finds obtained through floatation (seeds, insects and molluscs) is more complicated. The results of the radiocarbon (AMS) dating show that at least three samples represent a mixture of prehistoric Romanperiod (charred seeds and uncharred remains of Copris lunaris) and recent/modern material (some of the uncharred seeds). The number and density of uncharred seeds and the coincidence of a Roman-period beetle fragment and a seed of modern Datura stramonium in the same sample indicate that not all the uncharred plant material is modern or recent. We believe that modern/recent seeds originate from the ploughing horizon/subsoil and were introduced to the sampled sediment on the shoes of excavators (Figure 4). As the arable fallow and synanthropic ruderal vegetation has been dominant in the area since 1950, we suppose that only some of the finds of ruderal taxa are modern/recent. Which seeds of present ruderal taxa are modern/prehistoric is impossible to assess: a.) without their direct AMS dating; and b.) because no control sample was taken. It is also possible that seeds of the same taxa (excluding neophyte Datura stramonium) might be of Roman and of recent origin.

The origin of the fill and the processes that led to the accumulation of sediments within the pit are discussed by way of an evaluation of the finds recovered due to waterflotation. The number (and the density) of plant and small fauna remains in the samples varies. There are samples that are rich in finds and samples that are poor. Five samples contain more than 200 plant macro remains, and one with over 100 snail shells. The higher density of plant finds in a given volume of (waterlogged) sediment might be the result, for example, of the fast accumulation of the material or due to the existence of a barrier that was blocking erosion and consequent deposition of the sediment to the layer. The lower density of organic finds within sediments might indicate either a slower accumulation rate which was caused by a relatively increased rate of erosion of the sediment from the vicinity or some "artificial" deposition of findsfree sediment (e.g. the collapse of some walls, filling in of the structure by humans, etc.) Using this notion and the information on the varying densities of finds, we propose that the sampled layers within the pit evolved through a variety of types of accumulation processes or occurred in different environmental settings (e.g. a covered or protected structure, an unprotected or opened-up area, etc.) As the stratigraphy of the samples is unknown, we cannot specify in what order the different deposition rates occurred.

Despite differences in numbers and densities, both findspoor and finds-rich samples are similar in composition. In each sample, materials from a wide range of economic activities and ecological niches are mixed. Charred finds of cereals, pulses and arable weeds come from fields and gardens and represent wastes from the processing of harvested crops - household and kitchen waste. A similar origin can also be given for animal bones. Tanathocenoses identified through uncharred seeds of plants and mollusc species are comprised of taxa originally from very different - dry and wet, opened and forested - habitats (see also below).

The economic activities or natural events which resulted in the mixing and deposition of such variable material in every layer can only be hypothesised. The pit was situated at the edge of the settlement in the lowest elevation, it is therefore feasible to propose that it was in or nearby a marsh or wet meadow, probably partly ruderalised. If the pit was uncovered and open, (some) seeds of wet meadow or ruderal plants could enter the sediments naturally from the surrounding vegetation, while the seeds of dry and/or mesophytic grasslands must have been brought to the site from elsewhere, probably in the form of hay or in animal dung - and vice versa if the pit was originally in a dry environment. It follows that some finds found their way to the pit through settlement activities, like the discarding of waste materials. Similarly, the majority of wooden finds, including fragments of small branches, represents worked or used wood, and must have been placed into the pit through human activities.

Also unclear is the mechanisms that resulted in the deposition of the mollusc shells. The grassland snails could 
have been brought (and deposited in the pit) on the stems of harvested hay plants or might have lived in the stored and slowly decomposing (?) hay or wood litter discarded into the pit. Woodland snails could have come with collected (fire) wood and some snails might have fallen (crawled into, or were eroded) into the pit from the surrounding habitats.

The archaeological situation, and the excavation technique applied, do not allow us to clarify with certainty if the pit was originally dry (and served, for example, as a storage pit) or whether it was filled with water and used as a water hole or well. Nevertheless, as the organic materials are very well preserved (not decomposed), it is probable that the pit fill had formed in a permanently-waterlogged, anoxic environment and was originally filled with water.

If the structure originally served as a storage pit, it might then be argued that some part of the plant matter (the harvested hay and some branches) might have been used as an insulation of the bottom and walls of the pit (Kunz, 2004). In such a case, the sample representing this event should be situated at the very bottom, rich in uncharred seeds of meadow plants and should be free of household wastes (charred seeds, bones, daub, pottery, etc.) In addition, the plant remains could have survived only if the pit was flooded shortly after the deposition of the hay. None of the samples of the assemblage are like this.

If the pit served originally as a water hole or a well, then at least some sample(s) from the bottom-most layer should have been poor in household or settlement waste finds or should contain higher a proportion of remains of aquatic plants, insects and snails. The most similar to this characterisation is sample no 7 , containing only 4 animal bones and no charred seeds. However, few of the uncharred seeds present belong to that of arable weeds and meadow species, and the recovered snails (Planorbis planorbis and Segmentina nitida) are of stagnant and densely overgrown water bodies which can temporarily dry up.

All the recovered aquatic plants, which in the assemblage occur exclusively in samples rich in plant remains and with species from other habitats, are only known today from larger waterbodies. It is not certain they would survive in such a small pond. Similarly, all present "aquatic" snails namely Anisus spirorbis prefer habitats that temporarily dry out. They indicate that the water level in the structure fluctuated and temporarily dried out, or that they were imported to the structure from elsewhere (with hay from the wet, or in spring, flooded meadows?). The recovered insect species are all from habitats which do not resemble the condition of either a permanent or temporary waterbody in a pit, and neither a pit with a decaying accumulation of organic matter. They all seem to have been transported to the pit with other material.

The finds connected to the original function of the pit should be situated at its very bottom. Unfortunately, we do not have spatial information for the sediment samples (plant macro-remains and snails) or for the wood, bone or pottery finds. Furthermore, as explained above, none of the samples fits the "originally dry pit" or "originally waterlogged pit" scenario. Relying on the description of the excavation procedure, the character of the sediment samples and the recovered finds, we believe that all samples represent the secondary fill of the structure and that all finds, with the exception of some wooden artefacts (see below), do not define the original function of the structure.

\subsection{Palaeoenvironment}

The identified taxa of plants, molluscs and insects indicate the presence and exploitation of a wide range of habitats from wet (aquatic, temporary waterbodies), through moist (mesophytic and wet meadows, wet woodland) to dry (steppe, steppe-forest), and from shaded (forest), through semi-open (woodland, shrub-land) to open (grasslands).

Trees and shrubs identified in the charcoal and wood assemblage, and woodland herbs from the sediment samples, originate from mixed oak forests with oak, maple (Acer), ash (Fraxinus), and pomaceous fruit trees (Pomoidae). The presence of light-loving or light-demanding species like hazel (Corylus avellana), buckthorn (Frangula alnus), birch (Betula sp.) and others indicate that the forests were open and could be described better as woodland. The differentiation of the taxa to species is not possible by microscopic wood anatomy. The majority of the documented wood taxa prefer moist stands, but also occur in the wooded enclaves of central European forest-steppes; for example, some taxa from the Pomoidae group (Malus sylvestris, Pyrus communis), Corylus avellana, Quercus ceris, $Q$. petrea, $Q$. pubescens, Q. robur, Acer campestre, Tilia tomentosa, Ulmus minor, etc. (Chytrý, 2017). The geomorphology of the area suggests that both types - steppe forest on loess and/or sandy dunes and a type of floodplain forest in the terrain depressions - was present. Charcoal of willow/poplar indicates that the banks of (at least some) streams and waterbodies were wooded or at least bordered by trees.

The choice of using oak branches or shoots for poles used in wicker (straight, slightly bent and laterally flattened, fragments) is surprising. For this purpose, wood of hazel or willow often obtained from coppiced or pollard trees are usually used. Branches of oak on so-called standard tress are usually not very long and often not straight. Such branch forms can be obtained from coppiced or pollarded trees. It is tempting to propose that during the Roman period in the Hurbanovo area such a method had been applied for the management of at least some of the oak trees.

The ecological characteristics of the herbal plants, wild animals, mollusc and insect species indicate the openness of the exploited landscape and the presence of man-made (fields) and semi-natural grassland habitats (meadows and pastures). Among the plants from arable land, grassland and ruderal vegetation, the most numerous are a group of species indifferent to soil or habitat moisture: typical, for example, of areas with a fluctuating underground water table ( $c f$. Látková, 2017). Weeds and grassland taxa of dry and wet habitats are equal in numbers. Exclusive ruderals and other ruderals or weeds are only of moist and wet areas. Woodland taxa are not soil-moisture-specific. 
The wild mammals also document the presence of a wide range of habitats - from wet to dry, and from forested to open country. Deer and wild boar, though adaptable (eurytopic) animals, prefer forested biotopes, while weasel indicates ecotone conditions and more open landscape.

The snails, which are more moisture- and habitat-specific than the plants or mammals, show a slightly different picture. The number of taxa from open and forested habitats is equal. Among the species of grasslands there are more taxa of dry than of wet habitats. And even though the group of woodland snails includes taxa from wet (floodplain) forests, the species of dry shrub-land or forest-steppe stands are more numerous. The species which live in both open and forested landscape (euryvalent), prefer wet habitats. All the aquatic species prefer conditions of temporary (drying-out) waterbodies.

Among the insects, none of the recovered beetles are exclusively forest taxa. The three species which live in wet habitats, forested and open alike, are all carnivorous. One species lives on decaying wood. The remaining ten taxa are species of an open type of landscape, including arable fields and ruderal stands. They are either coprophagous ( 5 species) thriving in habitats of (or similar to) moderatelymoist pastures, or pantophagous (4 species) and carnivorous (1 species) living in dry, steppe-like or ruderalized stands.

When using ecological information on the plants, mammals, snails and insect species recovered from the studied archaeological feature (or an archaeological site), we have to be cautious. First, as shown and argued above, the majority of the preserved finds were brought to the structure through human activity and by humans that exploited the landscape. Thus, while they document the existence of certain habitats or stands in the landscape, they do not inform us where or how far away they were situated from the site; we can only assume that it was not far away. Furthermore, they do not inform us as to what proportion of the landscape these habitats covered. It follows then that while we cannot state to what extent the landscape had been open or forested, we do know that the exploited areas were mostly open or sparsely-wooded habitats on both dry and wet substrates. The open stands were covered by various types of grasslands, such as pastures and meadows, in addition to the (expected) synanthropic vegetation of ruderal stands, arable fields and gardens. Also, the forests seem to have had an open character; However. it is unclear if the openness was due to natural conditions or human impact. The possible local coppicing or pollarding of oak might cautiously point to a management of trees and therefore indirectly the reason for their sparseness. We therefore speak of woodlands or woodland habitats.

\subsection{Palaeoeconomy and subsistence}

The economy connected with the production and consumption of plant foods and arable farming practices of the barbaric (Germanic) population during the $1^{\text {st }}$ and $2^{\text {nd }}$ century AD of this region of south-west Slovakia has only been studied to date through the archaeobotany of charred plant remains (Hajnalová, Varsik, 2010). The results of this archaeobotany show the cultivation of a wide range of cereals and pulses. The staple crops (defined as the most common and most ubiquitous in the archaeobotanical record) of barley, millet and spelt wheat, differ in their proportions from site to site. In addition to these staples, the "more archaic" einkorn and emmer wheats were cultivated alongside the free-threshing wheat and rye, the cereals more typical for the Roman Provincial world. It remains unclear whether the cultivation of more-diversified cereal spectra (unlike the reduced spectra grown by Germanic populations on the territory of modern-day Bavaria, see Kreutz, 2004) is the result of a surviving "Celtic" tradition, the influence of the introduction of new staples from the Roman provinces, or a combination of the two (Hajnalová, Varsik, 2010). It is important to add that no vegetables and condiments or spices typical for the Roman cuisine, such as basil, dill, coriander, etc. (for review, see Bakels, Jacomet, 2002; Livarda, 2011), were recorded in the charred assemblages from "Germanic" settlements in the region of western Slovakia. They are absent even on sites where more systematic sampling and archaeobotanical research has been performed. If found at all, then they are present at the southernmost limits of the Slovakian territory, and thus on Roman provincial, civilian or military, sites (Hlavatá, 2017). Hurbanovo, with its finds preserved by waterlogging, and which document the utilisation of imported spices and medicinal herbs, such as dill or catmint, domesticated apple, and grapes/wine, is in this context unique. A similar situation also exists in the much better-studied West Europe. Exotic, luxurious, or in some other way "extraordinary" species of plants first occur at Roman military or civilian sites and only later, if at all, at settlements of the local "barbaric" populations (Stika, 1996; Matterne, 2001; Kreutz, 2004; Reddé, et al., 2005). In addition, they are more common at sites with waterlogged conditions than on "dry" sites where only charred plant remains are preserved (cf. Reddé, et al., 2005, p. 257).

The animal husbandry and meat diet of the barbaric populations living on the outskirts of the Roman Empire in east-central Europe has been studied mainly through the archaeozoology of hand-retrieved collections (e.g. Ambros, 1978; Peške, 1994; Vörös, 2002; Fabiš, 2003; Šefčáková, 2011; Fabiš, Bielichová, 2014; Bielichová, 2017; for a complete list of available published and unpublished data from Slovakia, see Bielichová, forthcoming). The results show that the economy of Germanic tribes settled in southwestern Slovakia was based on the keeping of domestic livestock with an additional supply from hunting and fishing. Wild animals also occurred in lower numbers than domesticated elsewhere north and east of the European Limes (Benecke, 1994; Bökönyi, 1974; Vörös, 2002). Although the analysed sample is rather small for a regional analysis, in Hurbanovo the NISP of wild animals, even excluding intrusive species, is markedly higher (18\%) than that reported from hand-collected assemblages from barbaric - Germanic or Sarmathian sites in the middle Danube region (e.g. Kratochvíl, 1980; Peške, 1994; Riedel, 1996; Dreslerová, 2006). It is clear that it is crucial to include the material obtained through water flotation as this provided 
the majority of wild species, including the usually rare fish bone and scale. As already pointed out (e.g. Salač, 2013, p. 62), fish were an important food resource: especially for communities living close to lakes and rivers. Regrettably, the rare use of more up-to-date excavation methods in Slovakia still amplifies a bias in the assessment of fishing.

The evaluation of the collected data suggests that cattle, caprines (mainly sheep) and pigs were the most important domestic species. The keeping of horses, dogs and chickens was common, while the goat and goose occurred in lower numbers. However, the vicinity of the Roman Empire increased trade and mobility, also manifested itself in the local animal husbandry through the introduction of new species: donkey as a draft animal (Fabiš, Bielichová, 2014); cats as pets (Kolník, 1962; Fabiš, Bielichová, 2014); and the pigeon, perhaps as a luxury food (Šefčáková, 2011). The occurrence of new and exotic species has also been reported from other barbaric sites in the Middle Danube region (e.g. Nývltová Fišáková, Šedo, 2003; Biller, 2017). Although the evidence from Slovakia is far from representative, the archaeozoology shows variable local patterns in the exploitation of animals. The NISP, WISP, ageing and butchery data suggest that the most significant animal was the cow, intensively exploited (also in Hurbanovo) for its meat and labour. The MNI indicates that cattle and pigs were slaughtered in equal numbers at Bratislava-Trnávka (Šefčáková, 2011), Trnava (Bielichová, 2017), Vel'ké Zálužie and other Germanic sites from the southwest Slovakia (Bielichová, forthcoming). The importance of pigs slightly increases towards the $3^{\text {rd }}$ and $4^{\text {th }}$ century AD (later than the occupation of Hurbanovo) in the region of Bratislava (Šefč́aková, 2011, p. 392) situated on the Limes, which might be the result of an archaeologicallydetected increase in the local population (Varsik, 2011) and/ or the Romanization of the diet (e.g. King, 1999; 2001). The Roman-provincial military sites in Slovakia, such as IžaLeányvár (Ambros, 1986; Šimunková, 2013) and BratislavaRusovce (Šefčáková, 1993), show the tendency for a higher consumption of lamb/mutton dishes, while at other sites elsewhere on the Pannonian borders, beef and pork dishes prevailed (e.g. Bökönyi, 1984; Bartosiewicz, 1989; Kunst, 2002).

Even if the Slovak data are biased, it is tempting to speculate that the predominance of bones of cattle and caprines over pig (in WISP and NISP) during the early Roman period may, in Hurbanovo, illustrate the continuity of the earlier, Iron Age, "rural-diet tradition" (Peške, 1994; see also Albarella, 2007; Lyublyanovics, 2010). Yet the analysed sites from the La Tène period (Fabiš, 2000; 2002), and its comparison to the Late Roman period settlements at Nitra-Chrenová (Fabiš, 2003; see also Fabiš, Miklíková, 2002) and Vel'ký MederVámostelek (Fabiš, Bielichová 2014), suggest the persisting importance of sheep in both its uses: the meat diet as well as animal husbandry. The morphometric data, which would allow a discussion on continuities or changes in livestock size (cf. Šefčáková, 2011, pp. 401-402; Fabiš, 2003, p. 09; Fabiš/Bielichová, 2014, pp. 177-179; Bielichová, 2017) as indicators of an influence from the Romanized world (e.g. Bielichová, 2017; Valenzuela-Lamas, Albarella, 2017; Rizzeto, Crabtree, Albarella, 2017), are in Hurbanovo insufficient. However, the horn anatomy suggests the presence of a short-horned (brychyceros) cattle type, typical for Celtic and Germanic settlements in the Middle Danube area (see Bökönyi, 1974, p. 127).

The small numbers of horse and dog bones in Hurbanovo also points to the exploitation of these animals for their meat (horse pelvis with dog gnawing, mandible fragment with cut/chop marks) and brain tissue (dog cranium with disrupted braincase). Similar indicators of hippophagia has been sporadically reported from other contemporary sites of the region (e.g. Miklíková, 2003, p. 92; Fabiš, Bielichová, 2014, p. 175). For the northern region, the consumption and/or exploitation of dog meat is known from the Iron Age and Early Roman settlement at Liptovská Mara (Chrózscz, Janeczek, Miklíková, 2010; Chrózscz, et al., 2015).

To sum up, the evaluated assemblage of floral and faunal remains, even if retrieved from a single man-made structure, brings new, well-dated evidence on the exploitation of plants and animals during the first century AD. For archaeozoology, the assemblage represents the second site for the region and period with animal bones. For archaeobotany, the material changes our understanding of dietary habits, crop husbandry and the contacts of the (local barbaric) Germanic population living outside, but not far from, the borders of the Roman province of Pannonia.

\subsection{Original function of the pit}

Mostly due to the scarcity of naturally-waterlogged conditions in the Middle Danube area, the pit from Hurbanovo, situated on the edge of a marsh, dug below the level of the underground water table, and without a clear lining of the walls, represents a very specific and unique find.

Settlement pits of similar dimensions and shape as the pit from Hurbanovo are common features at Roman-period, Germanic sites in the Middle Danube region. They are, however, as a rule, dug into dry bedrock deposits, originally serving as storage spaces for crops or other products, and were then later often filled with settlement wastes ( $c f$. Droberjar, 1997, p. 17, p. 19; Kolník, 1962, pp. 390-391; 1998, p. 153; Kolník, Varsik, Vladár, 2007, p. 20). Structures dug deeper and/or into waterlogged deposits are rare (e.g. in Slovakia, only recorded at 8 Roman period sites). The complete dimensions, shape, and presence or form of the lining are only known for two pits from the sites of Bratislava-Trnávka (Varsik, 2011) and Cífer-Pác (Kolník, 1986). At both these sites the bottom part of the feature was lined with a wooden, timberframe construction. In Cífer-Pác, this was also combined with a stone lining. At other sites, excavations stopped at the underground water-table, when the water started to fill the excavated feature. Although the original dimension, shape and presence or form of the lining of these structures is unknown, all are interpreted as wells (Maixnerová, 2015) even if other functions might have been considered.

For example, the archaeological and archaeobotanical literature from Poland and Denmark has already recognised 
for over two decades structures described as wells and/or retting pits. In Denmark they date from the late Bronze Age to pre-Roman Iron Age ( $800 \mathrm{BC}$ to $1050 \mathrm{AD}$; Andersen, Karg, 2011), and in Poland they are found at sites of the Przeworsk Culture of the late Iron Age and Roman period (ca 400 BC to 400 AD; Bednarczyk, 1998, p. 73; Nierychlewska, Tyszler, 2008-2009, p. 107; Żychliński, 2010; Skowron, 2010, pp. 428-429, Table XI: 4; Siciński, Mueller-Bieniek, Skawińska-Wieser, 2015). They have a circular or oval ground-plan (2-2.8 $\mathrm{m}$ in diameter), are funnel-shaped in profile, reach down below the underground water table, and have some form of lining/securing of the walls (1-1.5 $\mathrm{m}$ in diameter), usually made of wood and often preserved only in their lower part. In Poland, the distinction between retting pits and wells is based on their dimensions and the form of the lining. Wells are (sometimes only slightly) deeper then retting pits and have walls lined by various timber constructions of usually a square, but also oval or triangular, ground plan. The retting pits are shallower and the walls are secured by a "basket" - a wicker (wattle) entwined around vertically-fastened pegs forming a circular structure. The majority of the finds (ceramic, bone, metal, and if taken, also plant macro-remains) recovered from the fill of both wells and retting pits seem not to be connected to the pit's original function and represent settlement wastes discarded to the pit after its function had been abandoned. The exceptions are flax stems recovered from a pit at Karczyn (Bednarczyk, 1998, p. 73) and a wooden, flat, shovel-like object from the lower layer of the pit at Klonia Orenice 2 (Siciński, Mueller-Bieniek, Skawińska-Wieser, 2015, Figure 8.1). Identical objects are known from the ethnography of eastern Europe to have been used either for washing linen or clothes, or for beating the stems of flax, during flax-fibre processing. In Denmark, the function of a retting pit has been ascribed to pits where the lower fill layers yielded bundles of stems (sometimes also capsules and seeds) of flax (Linum usitatissimum). The wooden lining of retting pits from Denmark varied from hollowed tree trunks, through baskets, to wooden timber.

The walls of the pits for flax or hemp retting recorded in the history and ethnography of Slovakia Moravia, have never been fastened with wooden or basketry structures (Zajonc, 2012). However, their bottoms or walls were sometimes lined with straw or twigs to prevent the stems of flax or hemp touching the mud (Zajonc, 2013). The retting pits in Slovakia and Bohemia were often situated in marshy areas near streams (Kunz, 2006).

In Hurbanovo, the variability and number of wellpreserved wood remains indicate the constant saturation of the sediments by water (permanently-waterlogged, anoxic conditions), at least during the formation of the structure's fill. The presence of some original lining of the walls is unclear. If part of the recovered finds do indeed represent it, than it would have originally had to be a wattle structure formed by vertical pegs/posts entwined with horizontal poles. However, the majority of the pegs and poles were not positioned at the bottom or along the walls, but scattered throughout the fill.
In addition, several wooden finds carried puncture marks caused by nails, while no nails were found. We see this as evidence that the wooden artefacts more probably represent refuse from some dismantled wooden structure(s) and not an original structure in the pit.

To summarise, the archaeological situation and known archaeological analogies indicate that the pit from Hurbanovo, lacking a clear fastening of the walls by some wooden or stone structure, was most probably not a source of drinking water - a well. It might have been a retting pit as supported by ethnography, but also could have been a source of water for animals or some household use other than drinking.

\section{Acknowledgements}

The authors would like to thank Peter Červeň (Institute of Archaeology SAS in Nitra) for assembling the maps and images and two reviewers for useful comments on the manuscript. The work has been supported by the VEGA projects nr. 1/0399/18, 1/0243/17, 2/0079/18 and by the APVV-15-0491.

\section{References}

ALBARELLA, U., 2007. The End of the Sheep Age: People and Animals in the Late Iron Age. In: C. Haselgrove, T. Moore, eds. The Late Iron Age in Britain and Beyond. Oxford: Oxbow Books, 389-402.

AMBROS, C., 1978. Prírastky a analýzy archeozoologického materiálu. Archeologické výskumy a nálezy na Slovensku 1977, 19-27.

AMBROS, C., 1986. Iža-Leányvár. MS. Research report, nr. 11619/86. Deposited: Archive of the Institute of Archaeology, Slovak Academy of Sciences, Nitra.

AMBROS, C., MÜLLER, H.-H., 1980. Frühgeschichtliche Pferdeskelettefunde aus den Gebiet der Tschechoslowakei. Archaeologica Slovaca - Fontes, Tomus XIII, Bratislava:Veda.

ANDERSEN, S.T., KARG, S., 2011. Retting pits for textile fibre plants at Danish prehistoric sites dated between 800 B.C. and AD 1050. Vegetation History and Archaeobotany 20, 517-526.

ANDRÉ, J., 1981. L'alimentation et la cuisine à Rome. Coll. d'Etudes Anciennes publiées sous le patronage de l'Ass. G. Budé. Revue des Études Anciennes 85, Paris: Les Belles Lettres.

BARTOSIEWICZ, L., 2013. Shuffling Nags, Lame Ducks. The archaeology of Animal Disease. Oxford: Oxbow Books.

BEDNARCZYK, J., 1998. Życie codzienne w okresie rzymskim. In: Chłodnicki, M., Krzyżaniak, L., eds. Pipeline of Archaeological Treasures. Gazociag pełen skarbów archeologicznych. Poznań, 73-98.

BEHRENSMEYER, A.K., 1978. Taphonomic and ecologic information from the bone weathering. Paleobiology 4(2), 150-162.

BIELICHOVÁ, Z. 2017. Archaeofaunal remains from the Roman period settlement pit at Trnava-Horné pole, southwestern Slovakia. Acta Rer. Natur. Mus. Nat. Slov., Vol. LXIII, 111-134.

BIELICHOVÁ, Z., forthcoming. Animals and the economy of Germanic peoples: archaeozoological evidence from the Late Roman period site at Vel'ké Zálužie, SW Slovakia. Slovenská Archeológia, 67(2).

BÖKÖNYI, S. 1974. History of domestic mammals in Central and Eastern Europe. Budapest Akadémiai kiadó.

BRONK RAMSEY, C., 2013: OxCal 4.2.3. [online]. Available from: http:// c14.arch.ox.ac.uk/oxcal/OxCal.html retrieved June 14th 2017.

DRIESCH, A. von den, 1976. A guide to the measurement of animal bones from archaeological sites. Harvard: Peabody Museum of archaeology and Ethnology, Harvard University. 
DROBERJAR, E., 1997. Studien zu den germanischen Siedlungen der älteren römischen Kaiserzeit in Mähren. Fontes Archaeologici Pragenses 21. Praha: Archeologický ústav AV ČR, Praha.

FABIŠ, M., 2000. Analyse der Tierreste aus der Latèneteitlichen Siedlung In: Březinová G.: Nitra-Šindolka: Siedlung aus der Latènezeit. Katalóg. Archaeologica Slovaca Monographiae 7, Bratislava: Veda, 299-334.

FABIŠ, M. 2002. Skeletové zvyšky zvierat z laténskej doby na hradnom vrchu v Nitre. Agriculture (Pol’nohospodárstvo), 48(8), 465-443.

FABIŠ, M., 2003. Archeozoologická analýza (1996-2000). In: Březinová, G., Benediková, L., Fabiš, M., Hajnalová, M., Hunka, J., Illášová, L., Jakab, J., Kuzmová, K., Vondráková, M.: Nitra-Chrenová. Archeologický výskum na plochách stavenísk Shell a Baumax. Archaeologica Slovaca Monographiae, Catalogi 9, Nitra, 99-131.

FABIŠ, M., BIELICHOVÁ, Z. 2014. Úvodná štúdia k archeozoológii vo Vel'kom Mederi. Študijné zvesti Archeologického ústavu SAV 56, 169-182.

FABIŠ, M., MIKLÍKOVÁ, Z., 2002. Chov zvierat na území dnešnej Nitry na prelome vekov. In: Zborník z medzinárodného seminára vedeckých pracovnikov „Aktuálne problémy riešené v agrokomplexe“ konaného 15.11.2002 na SPU v Nitre. Nitra, 271-273.

FERIANCOVÁ-MASÁROVÁ, Z., HANÁK, V., 1965. Stavovce Slovenska IV. Cicavce. Bratislava: Veda.

HAJNALOVÁ, M., RAJTÁR, J., 2009: Supply and subsistence: the Roman Fort at Iža. In: Hanson, W.S., ed. The Army and Frontiers of Rome. Papers offered to David Breeze on the occassion of his sixty-fifth birthdays and his retirement from Historic Scotland. Porthsmouth, Rhode Island. Journal of Roman Archaeology. Supplementary series 74, 194-208.

HAJNALOVÁ, M., VARSIK, V., 2010. Kvádske rol'níctvo na Slovensku z pohl'adu archeológie a archeobotaniky. In: Beljak, J., Březinová, G., Varsik, V., eds. Archeológia Barbarov 2009. Hospodárstvo Germánov. Sídliskové a ekonomické štruktúry od neskorej doby laténskej po včasný stredovek. Archaeologica Slovaca monographiae, Communicationes 10, Nitra, 181-224.

HANZELYOVÁ, E., KUZMA, I., RAJTÁR, J., 1995. Letecká prospekcia na juhozápadnom Slovensku. Archeologické výzkumy a nálezy na Slovensku 1993, 1995, 54-58.

HAKBIJL, T. 2000. Arthropod remains as indicators for taphonomic processes: an assemblage from $19^{\text {th }}$ century burials, Broerenkerk, Zwolle, The Netherlands. In Huntley, J.P., Stallibrass, S., eds. Taphonomy and Interpretation. Symposia of the Association for Environmental Archaeology 14. Oxford: Oxbow books, 95-96.

HLAVATÁ, J., 2017. Rastlinné potraviny, ich produkcia, úprava a skladovanie v germánskom a rímsko-provinciálnom prostredí na území stredného Dunaja. MS, Unpupblished PhD. Theses, UKF, Nitra.

HŮRKA, K., 1996. Carabidae of the Czech and Slovak Republics. Zlín: Kňourek.

CHRÓSZCZ, A., JANECZEK, M., MIKLÍKOVÁ, Z., 2010. Animal remains from Liptovská Mara, northern Slovakia: a preliminary report. In: Beljak, J., Březinová, G., Varsik, V., eds. Archeológia Barbarov 2009. Hospodárstvo Germánov. Sídliskové a ekonomické štruktúry od neskorej doby laténskej po včasný stredovek. Archaeologica Slovaca monographiae, Communicationes 10, Nitra, 225-237.

CHRÓSZCZ, A., JANECZEK, M., ONAR, V., STANIOROWSKI, P., POSPIESZNY, N., 2007. The Shoulder Height Estimation in Dogs based on the Internal Dimension of Cranial Cavity using Mathematical Formula. Anat. Histol. Embryol. 36, 269-271.

CHRÓSZCZ, A., JANECZEK, M., BIELICHOVÁ, Z., GRALAK, T., ONAR, V., 2015. Cynophagia in the Púchov (Celtic) Culture Settlement at Liptovská Mara, Northern Slovakia. International Journal of Osteoarchaeology 25, 528-538.

CHYTRÝ, M., 2017. Curent Vegetation of the Czech Republic. In: Chytrý, M., Danihelka, J., Kaplan, Z., Pyšk, P., eds., Flora and Vegetation of the Czech Republic. Plant and Vegetation 14, Springer, 231.

JELÍNEK, J., 1993. Check-list of the Czechoslovak Insets IV (Coleoptera). Folia heyrovskyana, Supplementum 1, Praha, 172.

KENWARD, H.K., HALL, A.R., JONES, A.K.G., 1980. A tested set of techniques for the extraction of plant and animal macrofossils from the waterlogged archaeological deposits. Science and Archaeology 22, 3-15.

KING, A.C., 1999. Diet in the Roman world: a regional inter-site comparison of the mammal bones. Journal of Roman Archaeology 12, 168-202.

KING, A.C., 2001. The Romanization of diet in the western Empire: comparative archaeozoological studies. In: Keay, S., Terrenato, N., eds. Italy and the West: Comparative Issues in Romanization. Oxford, 210-223.

KOLDA, J., 1936. Srovnávaci anatomie zviřat domácích se zřetelem $k$ anatomii člověka. Brno: Novina.

KOLNÍK, T., 1962. Nové sídliskové nálezy z doby rímskej na Slovensku. Archeologické rozhledy 14, 344-397.

KOLNÍK, T., 1986. Römische Stationen im Slowakischen Abschnitt des Nordpannonischen Limesforlandes. Archeologické rozhledy 38, 411-434.

KOLNÍK, T., VARSIK, V., VLADÁR, J. 2007. Branč. Germánska osada z 2. až 4. storočia. Archaeologica Slovaca Monographiae Catalogi 10. Nitra 2007.

KOLNÍKOVÁ, E., 2002. Eine römische Bleiplombe aus Hurbanovo - der erste Fund in der Slowakei. In: Kuzmová, K., Pieta, K., Rajtár, J., eds. Zwischen Rom und dem Barbaricum. Festschrift fur Titus Kolník zum 70. Geburstag. Nitra, 295-303.

KREUTZ, A., 2004. Landwirtschaft im Umbruch? Archäobotanische Untersuchungen zu den Jahrhunderten um Christi Geburt in Hessen und Mainfranken. Berichte RGK 85, 97-292.

KRIŠTOFÍK, J., DANKO, Š., eds., 2012. Cicavce Slovenska. Rozširenie, bionómia a ochrana. Bratislava: Veda.

KUNZ, L., 2004. Obilní jámy. Rolnictví na východní Moravě od baroka do II. světové války 1. Rožnov pod Radhoštěm: Valašské muzeum v př́rodě.

KUNZ, L., 2006. Osedlý rolnik. Rolnictví na východní Moravě od baroka do II. světové války 3. Rožnov pod Radhoštěm: Valašské muzeum v přírodě. KYSELÝ, R., 2005. Archeologické doklady divokých savců na území ČR v období od neolitu po novověk. Lynx 36, 55-101.

LÁTKOVÁ, M., 2017. The Archaeobotany of Mikulčice. Food Supply to the Early Medieval Stonghold. Brno: Archeologický ústav AV ČR Brno.

LOŽEK, V., 1964. Quartärmollusken der Tschechoslowakei. Praha: Nakladatelství Československé akademie věd.

LYMAN, R.L., 1994. Vertebrate taphonomy. $1^{\text {st }}$ ed. Cambridge: Cambridge University Press.

LYUBLYANOVICS, K., 2010. Animal Keeping and Roman Colonization in the Province of Panonia Inferior, Western Hungary. In: Campana, D.V., Crabtree, P., de France, S.D., Lev-Tov, J., Choyke, A.M. eds. Anthropological Approaches to zooarchaeology: Colonialism, Complexity and Animal Transformations. Oxford: Oxbow Books, 182-193.

MAIXNEROVÁ, M., 2015: Studny z doby řmské a doby stěhování národi̊. MS. Unpublished Bachelor Diploma Thesis, ÚAM FF MU, Brno.

MÉNIEL, P., 2008. Manuel D’Archéozoologie Funéraire et Sacrificielle. Âge du Fer. En Crausaz, Gollion: Infolio.

MEYRICK, R.A., PREECE, R.C., 2001. Molluscan successions from two Holocene tufas near Northampton, English Midlands. Journal of Biogeography 28 (1), 77-93.

MIKLÍKOVÁ, Z., 2003. Zvieracie zvyšky z doby rímskej v Beluši. Archeologické výskumy a nálezy na Slovensku 2002, 92-93.

NĚMEJCOVÁ-PAVÚKOVÁ, V., 1979. Počiatky bolerázskej skupiny na Slovensku. Slovenská Archeológia 27, 17-55.

NIERYCHLEWSKA, A., TYSZLER, L., 2008-2009: Badania w Witowie na stanowisku 14 - 15, gm. Piątek, pow. Łęczyca, woj. Łodzkie, na trasie autostrady A 1 (st. A1 72 - 73). Zarys problematyki badań. Prace i Materiaty Muzeum Archeologicznego i Etnograficznego w Lodzi, Seria Archeologiczna 44, 103-124.

PEARSALL, D. M., 2000. Palaeoethnobotany - a handbook of procedures. London: AcademicPress.

PEŠKE, L., 1994. Osteologické nálezy z Mlékojed o. Mělník ze starší doby římské. Archaeologické rozhledy 46, 306-318.

RAJTÁR, J., 2002. Zur Verbreitung der Fibeln Almgren 43 im Mitteldonaugebiet. In: Kuzmová, K., Pieta, K., Rajtár, J. eds. Zwischen Rom und dem Barbaricum. Festschrift fur Titus Kolník zum 70. Geburstag. Nitra, 355-364.

RAJTÁR, J., 2004. Záchranný výskum v Hurbanove. Archeologické výskumy a nálezy na Slovensku 2003, Nitra, 145-150.

RATIMORSKÁ, P., 1998. Praveké a včasnostredoveké osídlenie Hurbanova vo svetle archeologických výskumov a nálezov. In: Studia Historica Nitriensia 7, Nitra, 35-45.

REIMER, P.J., BARD, E., BAYLISS, A., BECK, J.W., BLACKWELL, P.G., BRONK RAMSEY, C. , BUCK, C.E. , CHENG, H.,EDWARDS, R.L., FRIEDRICH, M. , GROOTES, P.M. , GUILDERSON, T.P., 
HAJDAS, I. , HATTE, C., HEATON, T.J., HOFFMANNM, D.I., HOGG, A.G. , HUGHEN, K.A., KAISER, K.F. , KROMER, B., MANNING, S.W., NIU, M., REIMER, R.W., RICHARDS, D.A., SCOTT, E.M., SOUTHON, J.R., STAFF, R.A., TURNEY, C.S.M., VAN DER PLICHT, J. 2013. INTCAL13 and MARINE13 radiocarbon age calibration curves, $0-50,000$ years cal. BP. Radiocarbon 55, 1869-1887.

REITER, E., 1916. Fauna Germanica. In: Die Käfer des Deutschen Reiches 5. Stuttgart: G. Lutz Verlag, $153-168$.

REITZ, E.J., WING, E.S., 1999. Zooarchaeology. $1^{\text {st }}$ ed., Cambridge: Cambridge University Press.

RIZETTO, M., CRABTREE, P.J., ALBARELLA, U., 2017. Livestock Changes at the Beginning and End of the Roman Period in Britain: Issues of Acculturation, Adaptation, and 'Improvement. European Journal of Archaeology 20(3), 535-556.

RIXSON, D., 1988. Butchery evidence on animal bones. Circaea 6(1), 1988, 49-62.

SCHMID, E., 1972. Atlas of animal bones. Amsterdam - London - New York.

SICIŃSKI, W., MUELLER-BIENIEK, A., SKAWIŃSKA-WIESER, K., 2015: Kolonia Orenice st. 2, pow. Łęczyca. Makroskopowe szczątki roślinne jako wskaźnik charakteru użytkowego roszarni kultury przeworskiej z wczesnego okresu wpływów rzymskich. In: Tyszler, L., Droberjar, E., eds. Archeologia barbarzyńców 2014. Barbari superiores et inferiores. Łodź - Wieluń, 349-367.

SIMPSON, T., 2001. The Roman Well at Paddington, Northamptonshire, England: an Investigation of the Coleopterous Fauna. Environmental Archaeology 6, 91-96.

SILVER, I.A., 1969. The ageing of domestic animals. In: Brothwell, D.R., Higgs, E.S., eds. Science in archaeology: a survey of progress and research, $2^{\text {nd }}$ ed., New York, 250-268.

SKOWRON, J., 2010. Obiekty produkcyjne z osad ludności kultury przeworskiej v Polsce środkowej. In: Beljak, J., Březinová, G., Varsik, V., eds. Archeológia barbarov 2009, Nitra, 419-448.

ŠEFČÁKOVÁ, A., 1993. Archeozoologické nálezy na území Bratislavy. In: Štefanovičová T., et al. Najstaršie dejiny Bratislavy. Bratislava, 332-337.

ŠEFČÁKOVÁ, A., 2011. Archeozoologická analýza nálezov z germánskych sídlisk na východnom okraji Bratislavy. In: Varsik, V.: Germánske osídlenie na východnom predpoli Bratislavy. Sídliská z doby rímskej v Bratislave-Trnávke a okolí. Nitra 2011, 385-404.
ŠIMUNKOVÁ, K., 2013. Úžitková keramika a archeozoologické nálezy z drevozemnej fázy rímskeho tábora $v$ Iži. MS. Master diploma thesis, AVN 310. Deposited: Archive of the Institute of Archaeology, Slovak Academy of Sciences, Nitra.

ŠUSTEK, Z., 1995. Fluktuácie populácií druhov Pterostichus melanarius a Pterostichus niger (Col. Carabidae) a ich interpretácia. In: Svobodová, A., Lisický, M.J., eds. Výsledky a skúsenosti z monitorovania bioty územia ovplyvneného vodným dielom Gabčikovo. Bratislava: Ústav zoológie a ekosozológie SAV, 314-318.

ŠUSTEK, Z., 2004. Characteristis of humidity requires and relation to vegetation cover of selected Central European Carabids (Col. Carabidae). In: Polehla, P., ed. Hodnocení stavu a vývoje lesnich geobiocenóz. Sbornik príspevků z mezinárodni konference 15. - 16. 10. 2004 v Brně. Geobiocenologické spisy 9. MZLU v Brně, 210 - 214.

TESA Ř, Z., 1957. Brouci listorozi II. Fauna ČSR 11, Praha: Nakladatelství ČSAV.

UERPMANN, H.-P., 1973. Animal bone finds and economic archaeology: a critical study of "osteo-archaeological" method. World Archaeology 4(3), 307-322.

VALENZUELA-LAMAS, S., ALBARELLA, U., 2017. Animal Husbandry across the Western Roman Empire: Changes and Continuities. European Journal of Archaeology 20(3), 402-415.

VARSIK, V., 2011. Germánske osídlenie na východnom predpoli Bratislavy. Sídliská z doby rímskej v Bartislave-Trnávke a v okoli. Archaeologica Slovaca Monographiae, Fontes 18, Nitra.

VÖRÖS, I., 2002. Farm and hunted animals from the Roman Imperial period in Hungary (a sketch). Specimina Nova Universitatis Quinqueecclesiensis $16,227-242$

ZAJONC, J., 2012. Premeny vlákna. Trnava: Ryba.

ZAJONC, J., 2013. Návod na pestovanie l'anu a konopy z roku 1789. Ethnologia Europea Centralis 11, 19-30.

ŻYCHLINSKI, D., 2010. Roszarnia lnu ze stanowiska 21 w Daniszewie, pow. Koło, woj. wielkopolskie jako przyczynek do poznania gospodarki ludności kultury przeworskiej z początków młodszego okresu przedrzymskiego. In: Beljak, J., Březinová, G., Varsik, V., eds. Archeológia barbarov 2009, Nitra, 537-543. 
